\title{
Impact of Fuel Composition Transients on SOFC Performance in Gas Turbine Hybrid Systems
}

\author{
Nor Farida Harun ${ }^{\mathrm{a}}$, David Tucker ${ }^{\mathrm{b}}$, Thomas A. Adams II ${ }^{\mathrm{a}}$ \\ ${ }^{a}$ Department of Chemical Engineering, McMaster University, 1280 Main Street West, Hamilton, Ontario L8S \\ 4L7, Canada \\ ${ }^{b}$ U.S. Department of Energy, National Energy Technology Laboratory, 3610 Collins Ferry Road, Morgantown, \\ West Virginia 26507-0880, United States
}

\begin{abstract}
This paper presents a dynamic study of fuel cell gas turbine (SOFC/GT) hybrid systems, focusing on the response to a drastic transient in anode fuel composition for constant turbine speed operations. This work is motivated by the potential of fuel cells for fuel flexibility, which could extend the opportunities for sustainability and profitability in energy conversion systems. A combination of hardware and numerical models in a hybrid simulator is used to investigate the transient trajectories of fuel cell process variables as well as the consequent impacts of fuel cell thermal effluent on the integrated gas turbine engine. The conversion of thermal energy stored in the fuel cell stack to chemical energy during the reforming at the beginning of the cell resulted in a $17 \%$ increase in thermal effluent from the fuel cell to the turbine in the first few seconds of the transient. Fuel cell solid temperature gradients increased by $39 \%$ at $250 \mathrm{~s}$ from the initiation of the transient. The distributed dynamic performance of the fuel cell in terms of the fuel composition gradient, thermal and electrochemical performance across the fuel cell length was carefully characterized, considering their interactions and their impacts on the total system performance.
\end{abstract}

Keywords: Fuel cell gas turbine hybrid; fuel composition transients; fuel flexibility; hardware-based simulations

\section{Nomenclature}

SOFC Solid oxide fuel cell

GT Gas turbine

NETL National Energy Technology Laboratory

APU Auxiliary power unit

SMR Steam methane reforming

WGS Water-gas shift

LHV Low heating value $[\mathrm{kW}]$

$T P B \quad$ Triple-phase boundary

$Q \quad$ Fuel cell waste heat/fuel cell net thermal effluent [kW]

$V_{\text {Nernst }} \quad$ Nernst potential [V]

$\Delta G_{H_{2} O}^{\circ} \quad$ Standard Gibbs free energy [kJ]

$F \quad$ Faraday's constant [C/mol]

$R_{u} \quad$ Ideal gas constant $[\mathrm{J} / \mathrm{mol}-\mathrm{K}]$

$T \quad$ Temperature [K]

$p \quad$ Partial pressure [atm]

$\alpha \quad$ charge transfer coefficient

$n \quad$ number of electrons transfer per reaction

$i \quad$ current density $\left[\mathrm{A} / \mathrm{cm}^{2}\right]$

$i_{0} \quad$ exchange current density $\left[\mathrm{A} / \mathrm{cm}^{2}\right]$

bulk anode/cathode stream

\section{Introduction}

Hybridization of high temperature fuel cells, such as solid oxide fuel cells (SOFCs), with gas turbines has been widely recognized as a compelling advanced power system for high efficiency energy production with low emissions. [1-4]. In particular, the SOFC gas turbine hybrid system offers an improvement of system efficiency by recovering high temperature waste heat from the fuel cell for additional power production from the gas turbine. In addition, it is discovered through research and development efforts initiated by the U.S Department of Energy using a pilot-scale system that the operating envelope of fuel cell gas turbine (SOFC/GT) hybrid

Corresponding author. Tel.:+1 9055259140 (ext. 24782); E-mail address: tadams@ @mcmaster.ca (Thomas A.

Adams II)

(C) 2015. This manuscript version is made available under the Elsevier user license 
systems has an opportunity to achieve $85 \%$ turndown [5]. This suggests that this hybrid system can possibly provide attractive solutions for sudden load excursions on the fuel cells, reducing impacts to both fuel cell and gas turbine during transient events or off-design operations [6].

The ability of high temperature fuel cells to directly use various types of fuels also greatly extends the interest in applications of fuel cell gas turbine (SOFC/GT) hybrid systems. Theoretically, it is feasible to run the SOFC/GT system using non-hydrogen fuels such as methane or biogas and even liquid fuels at selected operating conditions [7-10]. Furthermore, there are several potential applications where it might be very beneficial to have a power system that can handle drastic changes in the type of fuel used. First, if the market prices of fuels experiences sudden shifts, or, perhaps new regulations place environmental restrictions on the fuel type, it may be beneficial to switch the fuel used to take advantage of the new economic situation $[1,11]$. For example, suppose a power plant uses primarily gasified coal, but the price of natural gas suddenly drops, or, a new carbon tax takes effect; it could be more profitable to switch the main fuel from coal to natural gas.

Second, recent studies have shown that flexible polygeneration systems which co-produce electricity with fuels or chemicals can take advantage of monthly or even daily shifts in energy prices (such as electricity) by changing the mixture of products that it produces in response to these changing market conditions. [1, 11, 12].For example, one may want to produce more electricity and less fuels during the day when power prices are high, and then switch to producing more fuels and less electricity at night when power prices are low. To maximize efficiency, flexible polygeneration are designed to tightly integrate the chemicals/fuel production and electricity production sections such that when these transitions occur, the feed rates, heating value, and composition to the power generation system changes significantly $[11,13]$.

In either case, SOFC/GT systems are potentially a very suitable technology to use as the power generation mechanism since they are highly efficient and fuel-flexible. Although SOFC/GT hybrids can be used in both the power plant and polygeneration plant contexts, this study focuses on the former kind of transition (coal to natural gas) because it is the more extreme of the two.

However, SOFC/GT hybrid systems are not yet commercially ready due to practical problems associated with dynamic operations $[3,7,14,15]$. The highly interactive effects between fuel cell systems and turbine cycles during transient events always lead to complicated process dynamics that require problematic control development [16, 17]. For instance, although methane fueled systems can provide means to cool the fuel cell stack due to the endothermic reforming reaction [8,9], a dramatic temperature gradient across the fuel cell must be avoided to limit the thermal stress in the material [18]. Also, any variations in the fuel cell thermal effluent (which is the thermal energy of the SOFC exhaust streams) caused by transients in fuel composition can upset the stability of the turbine cycle, which in turn affects the fuel cell stacks $[19,20]$. Fuel starvation could be another potential failure in the system arising from the effects of transient behaviour [15, 21]. The result is that transient effects can cause complicated impacts to the fuel cell system and materials.

Despite many promising simulation studies that explore the operability of SOFCs using different type of fuels, there has been no prior published experimental data and/or detailed analyses of SOFC/GT system performance during fuel composition transients [22, 23]. To the best of our knowledge, almost all existing studies focus on steady state operations that are solely dependent on numerical simulations [7-9, 24-28]. However, if effective controls are to be developed to take advantage of the extensive operating envelope offered by SOFC/GT hybrids [5, 29], a dynamic characterization of fuel cell parameters is essential. Our understanding of the risks and challenges of fuel flexible SOFC/GT hybrid systems must be expanded through evaluation of the actual response and the coupling interactions of each component in the hybrid system. This effort requires more than prediction via simulations only.

Therefore, in this work, the dynamics of fuel composition changes in the recuperated direct-fired SOFC/GT hybrid system were experimentally investigated using a hybrid test facility with real recuperated turbomachinery equipment. This method was very beneficial to reduce high cost of using a real solid oxide fuel cell and to minimize large inaccuracies in simulating very fast turbomachinery dynamics. For instance, stall and surge in compressor/gas turbine could happen drastically during transient operations, in an order of milliseconds, which could cause catastrophic failure of both fuel cell and gas turbine/compressor. From the experience of researchers at National Energy Technology Laboratory (NETL), the real complexity of turbomachinery dynamics could not be sufficiently captured by simulation only.

While our prior work outlined the coupling effects on turbine portion of the system [30], this work characterized the detailed fuel cell dynamic trajectories in response to fuel transitions (specifically from coalderived syngas to humidified methane). As the first step in characterizing the distributed profile of key fuel cell variables, this paper was aimed at evaluating the overall contributions and linking effects of each fuel cell parameter to operability and controllability of the hybrid systems during fuel composition transitions. Emphasis of this work was placed upon the dynamic characterization of the hybrid system during fuel composition changes via hardware-based simulations using the existing real-time model of an SOFC. 


\section{Methodology}

\subsection{Hardware system}

A public testing facility of SOFC/GT at the U.S Department of Energy, National Energy Technology Laboratory (NETL), Morgantown, West Virginia, was used to carry out the test on fuel composition changes. As shown in a simplified flow diagram in Figure 1, this system combined a real-time fuel cell dynamic model (shown in the dashed-line box) and the balance of the plant for a potential recuperated SOFC/GT hybrid system $[31,32]$. The balance of the hybrid system was designed using real equipment and piping systems. With such configuration, this facility served as a valuable research tool in steady state or dynamic studies to explore the key operational challenges and opportunities of the SOFC/GT hybrid system in terms of dynamic control development for future system commercialization [3, 29, 33-37].

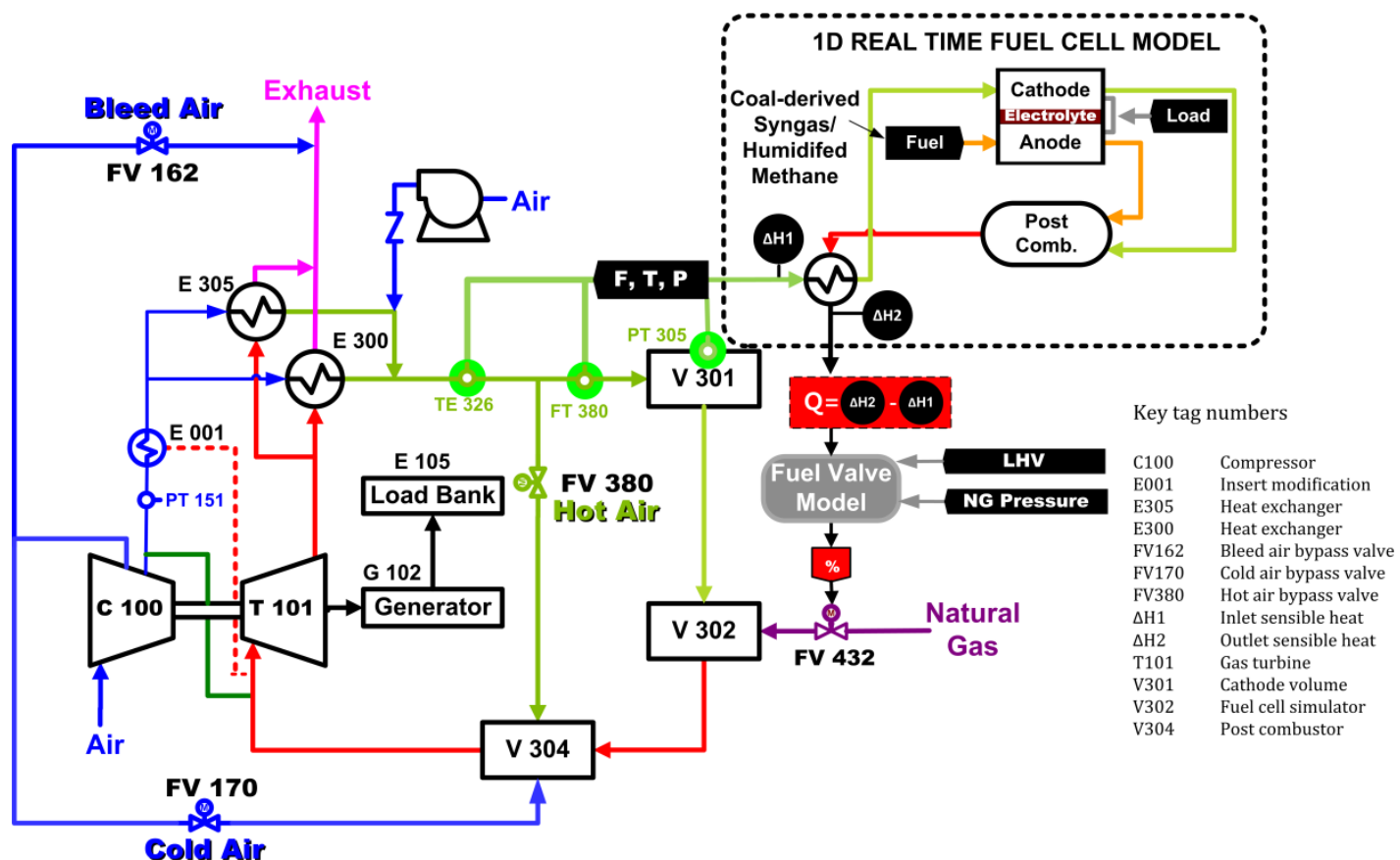

Figure 1: The physical system of SOFC/GT hybrid test facility at NETL. Reproduced from Harun et. al (2014)

A $120 \mathrm{~kW}$ auxiliary power unit (APU) consisting of a single shaft turbine (T-101) attached to a two-stage compressor (C-100), a $400 \mathrm{~Hz}$ gear-driven generator (G-102), and two primary surface heat exchangers (E-300 and E-305) were among the major parts of the hardware system. Air plenums were also used to emulate cathode volume (V-301) and post combustor volume (V-304) for a real direct-fired SOFC/GT system. In a constant turbine-speed operation, an adjustable $120 \mathrm{~kW}$ load bank system (E-105) was also connected to the system as an independent system variable to maintain the turbine speed.

In this work, the effect of the fuel cell waste heat was embedded in a fuel cell model output variable, which was the fuel cell model net thermal effluent, $Q$. The definition of $Q$ was simplified by the following equation, Eq. 1 [30], where $\Delta H_{1}$ and $\Delta H_{2}$ were the sensible heats of the cathode feed stream before preheating and the postcombustion exhaust after cooling with a reference to standard conditions, as shown in Figure 1. Meanwhile, $\dot{m}_{1}$ and $\dot{m}_{2}$ were the mass flow rate of the respective streams.

$Q=\dot{m}_{2} \Delta H_{2}-\dot{m}_{1} \Delta H_{1}$

During a fully coupled SOFC/GT test, a complete interaction cycle between the fuel cell model and the hardware system was achieved in real-time (as fast as $80 \mathrm{~ms}$ ) by feeding the sensor measurement of a real cathode feed stream in the hardware system to the software part as model inputs. To close the system loop, a model output (the fuel cell net thermal effluent) relevant to the study was fed to the hardware system in feedforward fashion. The $Q$ value was used to manipulate the natural gas flow through a real fuel valve $(\%$ FV432) simulating the energy input for turbomachinery.

\subsection{Model Description}

To achieve the objective of the case study presented herein, a previously developed one-dimensional (1D) real-time distributed fuel cell model was modified to enable fuel composition changes in the simulated SOFC 
fuel feed [31]. The implementation of fuel composition transitions in the emulator of solid oxide hybrid systems is graphically shown in Figure 2. The fuel cell model was based on an anode-supported fuel cell system with the standard material using 441SS interconnects and co-flow configuration [31]. The thermal behaviour of the materials used was characterized via curve fits based on temperature-dependent thermophysical properties at a broad temperature range (300K to $1800 \mathrm{~K})$ [31]. This model was verified with IEA benchmarking data sets and the result from other studies $[31,38,39]$.

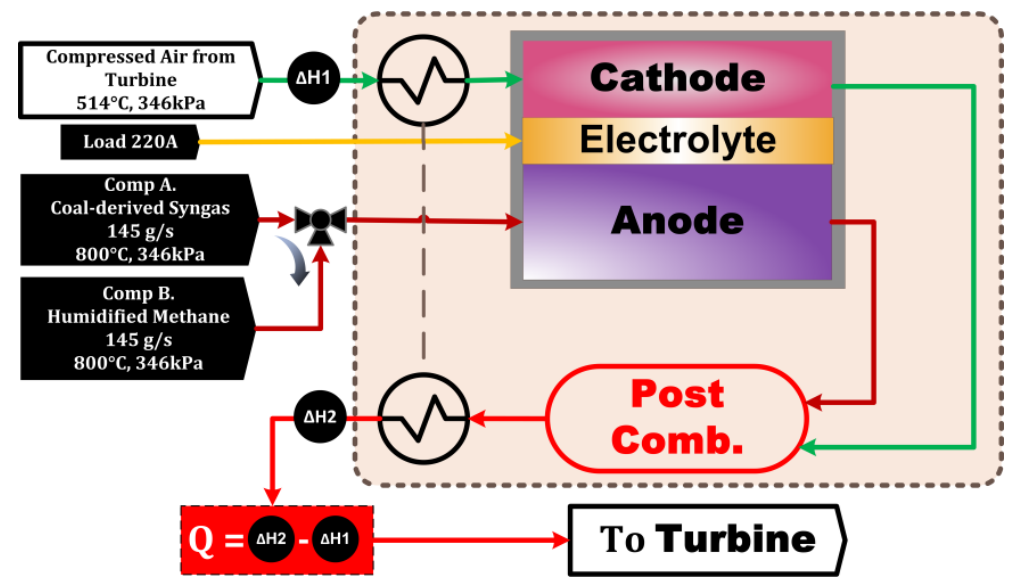

Figure 2: 1D-Real time fuel cell dynamic model.

This model was developed by considering the occurrence of both steam methane reforming and watergas shift reactions, in addition to electrochemical oxidation of hydrogen component only. This assumption was reasonable since it was shown that direct chemical oxidation of $\mathrm{CH}_{4}$ and $\mathrm{CO}$ resulted in negligible differences [38, 40-42]. The characterization of steam methane reformation was based on first order reaction kinetics as described in Eq. 2, where $A_{r x}$ is a pre-exponential factor, $T_{P E N}$ is the fuel cell solid temperature, and $R_{u}$ is the ideal gas constant $[38,43]$.

$r_{S M R}=4274 \frac{m o l}{s \cdot m^{2} \cdot b a r} p_{C H_{4}} \exp \left[\frac{-82,000^{J} / m o l}{R_{u} T_{P E N}}\right] A_{r x}$

Meanwhile, water-gas shift was presumed to occur at equilibrium at the selected operating range, and its equilibrium constant was empirically resolved as a function of temperature, as presented in Eq. 3, where $p_{i}$ is the partial pressure of component $i, x_{i}$ is the mole fraction of component $i$, and $T$ is temperature in Kelvin[31].

$K_{P, W G S}=\frac{P_{\mathrm{H}_{2}} P_{\mathrm{CO}_{2}}}{P_{\mathrm{H}_{2} \mathrm{O}} P_{\mathrm{CO}}}=\frac{x_{\mathrm{H}_{2}} x_{\mathrm{CO}_{2}}}{x_{\mathrm{H}_{2} \mathrm{O}} x_{\mathrm{CO}}}=\exp \left[\frac{4276}{T}-3.961\right]$

Given the initial operating condition as described in Table 1, at a desired set of fuel cell configuration parameters (Table 2) [30], the model simulated the distributed fuel cell profiles as function of time and local position for 20 nodes along the length of the cell in real-time based on the sensor measurements of recuperated compressed air being delivered to the cathode inlet (mass flow rate-FT380, temperature-TE326, and pressurePT305). Sensitivity studies showed that using 20 nodes provides the optimum balance in measurement speed and accuracy in capturing the fuel cell dynamics, particularly for millisecond time scales [44, 45]. It was shown that increasing the number of nodes above 20 did not improve the solution accuracy but increased the computational time exponentially [45].

The model evaluated most of the key fuel cell process variables, in terms of thermal performance including solid and gas temperature on the cathode side, axial heat generation within the cell, partial pressures of major components in the anode side, Nernst potential, polarization losses, and local current density [31, 44]. Implicit/explicit finite difference was the key methods used to determine the thermal performance along the fuel cell length. This also considered conductive heat for the solid material, convective heat transfer between the oxidant and the SOFC, and heat generation in the fuel cell as a result of chemical kinetics (i.e. water gas shift and steam methane reforming reactions) and electrochemical operations.

The model of temperature profile resolution is given in Eq. 4. $\beta$ is the fractional weighting of implicit formulation, $k$ is the effective thermal conductivity of solid, $A_{s}$ is the cross-sectional area for conduction heat 
transfer, while $A_{g}$ is the cross-sectional area for convective heat transfer. The term $\Delta x$ represents the spatial distance between the nodes, $\Delta t$ is the time step for each iteration, $n$ is the node, and $i$ is the iteration. The $H G_{\text {cell }}, H G_{W G S}$, and $H G_{S M R}$ respectively represent heat generated by the fuel cell due to electrochemical reactions, water gas shift, and steam methane reforming.

Temperature profile:

$\beta\left[\frac{k A_{S}}{(\Delta x)^{2}}\left(T_{i+1}^{n+1}-2 T_{i}^{n+1}+T_{i-1}^{n+1}\right)+h A_{g}\left(T_{\infty}-T_{i}^{n+1}\right)\right]+(1-\beta)\left[\frac{k A_{s}}{(\Delta x)^{2}}\left(T_{i+1}^{n}-2 T_{i}^{n}+T_{i-1}^{n}\right)+h A_{g}\left(T_{\infty}-\right.\right.$
$\left.\left.T_{i}^{n}\right)\right]+\left(H G_{\text {cell }}+H G_{W G S}+H G_{S M R}\right) A_{S}(\Delta x)=\rho C_{P}(\Delta x)\left[\frac{T_{i}^{n+1}-T_{i}^{n}}{\Delta t}\right]$

The cell voltage was ultimately calculated using Eq. 5, where $V_{N E R N S T}$ is the Nernst potential, $\eta_{\text {dif }}$, $\eta_{a c t}$, and $\eta_{\text {ohm }}$ respectively represent the diffusion loss, the activation loss and the ohmic loss. The polarization losses were calculated using Eq. 6 to Eq. 8. These equations were used based on the model assumptions. The experimental evidence and model validation have already been proven to support the model. Detailed work on model development including model assumptions, validations, and challenges of real-time fuel cell model applications in hardware-based simulations were discussed in a previous publication [31].

$V_{\text {cell }}=V_{\text {NERNST }}-\eta_{\text {dif }}-\eta_{\text {act }}-\eta_{\text {ohm }}$

$\eta_{\text {dif }}=\frac{R_{u} T}{2 F}\left(\ln \left(\frac{x_{\mathrm{H}_{2}, \text { bulk }} \cdot x_{\mathrm{H}_{2} O, T B P}}{x_{\mathrm{H}_{2} O, \text { bulk }} \cdot x_{\mathrm{H}_{2}, T B P}}\right)+\frac{1}{2} \ln \left(\frac{x_{O_{2}, \text { bulk }}}{x_{O_{2}, T B P}}\right)\right)$

$\eta_{a c t}=\frac{R_{u} T}{\alpha n F} \sinh ^{-1}\left(\frac{i}{2 i_{0}}\right)$

$\eta_{o h m}=R \cdot i$

The detailed fuel cell parameters and initial operating conditions used in this study are shown in Table 1. It was assumed that the initial fuel cell temperature was around $800^{\circ} \mathrm{C}$. As such, for simplification, the feed temperature of fuel was also at the same temperature. In this study, fuel manifolds for the fuel cell system were not modeled. Thus, autoreforming of methane was not considered.

Table 1 Inlet conditions for fuel cell cathode and anode streams. Based on Harun et.al [30]

\begin{tabular}{ll}
\hline & Measured cathode inlet condition at init \\
state & \\
Air mass flow rate & $1.04 \mathrm{~kg} / \mathrm{s}$ \\
Air temperature & $705^{\circ} \mathrm{C}$ \\
Air pressure & $346 \mathrm{kPa}$
\end{tabular}

Simulated anode inlet condition

Fuel mass flow rate $\quad 145 \mathrm{~g} / \mathrm{s}$

Fuel temperature $\quad 800{ }^{\circ} \mathrm{C}$

Fuel pressure $\quad 346 \mathrm{kPa}$

Table 2 Specification of SOFC system parameters. Based on Harun et.al [30].

\begin{tabular}{ll} 
Fuel cell load & $220 \mathrm{~A}$ \\
Anode recycle & $0 \%$ \\
Initial fuel cell temperature & $800{ }^{\circ} \mathrm{C}$ \\
Initial cell voltage & $0.83 \mathrm{~V}$ \\
Total cell area & $200 \mathrm{~mm} \times 200 \mathrm{~mm}$ \\
Anode thickness & $0.5 \mathrm{~mm}$ \\
Electrolyte thickness & $0.008 \mathrm{~mm}$ \\
Cathode thickness & $0.05 \mathrm{~mm}$ \\
Oxidant/fuel channel size & $2 \mathrm{~mm} \mathrm{x} 2 \mathrm{~mm}$ \\
Stack size & $2500 \mathrm{cells}$ \\
Total stack mass & $3500 \mathrm{~kg}$ \\
Total stack heat capacity & $2625 \mathrm{~kJ} / \mathrm{K}$ \\
\hline
\end{tabular}




\subsection{Hardware-based Simulation of SOFC Fuel Composition Transient}

The recuperated turbine cycle was first brought up to a nominal turbine speed at 40,500 rpm without the fuel cell model in the loop. Before integrating the fuel cell model into the test facility, the startup step was continued by heating the hardware system for about two hours to a thermally steady state condition, approaching $0.1 \mathrm{~K} / \mathrm{min}$ in the skin temperature gradient post combustor (V-304). During this period, a $40 \mathrm{~kW}$ turbine load and different bleed air bypass valve openings were used to accelerate the heating up process.

For this initial system steady state, the model input parameters for the fuel feed to the SOFC were specified to be $\mathrm{CH}_{4} 0 \%, \mathrm{CO}_{2} 12 \%, \mathrm{CO} 28.6 \%, \mathrm{H}_{2} 29.1 \%, \mathrm{H}_{2} \mathrm{O} 27.1 \%, \mathrm{~N}_{2} 3.2 \%$ (mole fraction). This coal-derived syngas was selected based on previous studies and because the SOFC/GT hybrid system properties are well known under these conditions [46, 47]. It was assumed that air composition in the cathode stream was $\mathrm{O}_{2} 21 \%$ and $\mathrm{N}_{2}$ $79 \%$. Since it has been shown that the overall SOFC/GT system efficiency of direct fired configurations was insensitive to fuel utilization in the fuel cell [48], a lower initial fuel utilization of $67 \%$ was chosen. However, the overall fuel utilization was not kept constant. Instead, the test was run at a constant fuel mass flow rate (145 $\mathrm{g} / \mathrm{s}$ ) and a constant fuel cell load (220 A). Thus, the impacts of fuel composition variations could be decoupled from the interaction of the changes in the mass flow and fuel cell load.

The integration of the real-time fuel cell model into the hybrid test facility was initiated once steady state conditions in both the recuperated hardware and the virtual SOFC system were achieved. The fuel feed was then switched from the initial steady state with the syngas composition to a methane rich fuel composition $\left(\mathrm{CH}_{4} 14 \%\right.$ and $\left.\mathrm{H}_{2} \mathrm{O} 86 \%\right)$ at the same fuel mass flow rate $(145 \mathrm{~g} / \mathrm{s})$. This step change represented a $17 \%$ reduction in the overall heat input (i.e. lower heating value of fuel) of SOFC system (Figure 2). No change was made in any other operating parameters during the fuel composition transition. This means that the operation using humidified methane was continued with the resulting steady state condition for syngas.

In a prior work, this composition was determined as a tolerable transition to ensure safe heat change in turbomachinery system in the hybrid configuration, and with this humidified methane mixture, no chance for the occurrence of carbon deposition [30]. Fuel diffusion effects were not taken into account. The step change from coal-derived syngas to this methane-rich fuel represented the "worst case possible" because this transition involved significant changes in each fuel constituent. It was expected that the effects of each fuel component could provide broad generality in terms of qualitative assessment, but the sensitivity of methane content could not be neglected. In a previous study, it was found that switching from coal-syngas to humidified methane with more than $14 \%$ methane could not be tolerated due to the transient limitations in the turbine cycle [30]. For transitions to fuels with larger than $14 \%$ methane, the fuel cell dynamics caused a rapid and extreme transient increase in the turbine speed which could destroy the turbine.

In this paper, the step time was indicated as time zero in the result plots. The transient profiles were observed for approximately 7,000 s after the step time. Based on operator experience, no significant transient response beyond 7,000 s of the experimental test was expected. The test was run at a constant fuel mass flow rate $(145 \mathrm{~g} / \mathrm{s})$ and a constant fuel cell load $(220 \mathrm{~A})$. Thus, the impacts of fuel composition variations could be decoupled from the interaction of the changes in the mass flow and fuel cell load.

\section{Results and Discussions}

\subsection{Distributed Analysis for the Initial Steady State with Coal-Derived Syngas Feed}

Due to the absence of methane $\left(\mathrm{CH}_{4}\right)$ content in the coal-derived syngas used in this study, as shown in Figure 3, the composition gradient of each gas component was primarily driven by the water-gas shift (WGS) kinetics (Eq. 9) and the electrochemical hydrogen $\left(\mathrm{H}_{2}\right)$ oxidation (Eq. 10). The direct electrochemical oxidation of $\mathrm{CO}$ and $\mathrm{CH}_{4}$ was assumed to be negligible, since (1) there is excess water in the system; (2) the kinetics of $\mathrm{CO}$ and $\mathrm{CH}_{4}$ oxidation are significantly slower than $\mathrm{H}_{2}$ oxidation; (3) less surface area is available for electrochemical oxidation at the three-phase-boundary as compared to the area available for catalytic reforming and WGS along the anode channel; and (4) $\mathrm{CO}$ and $\mathrm{CH}_{4}$ has slower mass transfer to the triple-phase boundary [40].

As clearly illustrated in Figure 3, the most rapid reduction in $\mathrm{CO}$ appeared to be at the first two nodes or $10 \%$ of the cell length, diminishing by $20 \%$. The sharp initial decline in CO partial pressure was due primarily to the shifting of $\mathrm{CO}$ to obtain the equilibrium condition. This was followed by the slow almost linear decline in $\mathrm{CO}$ towards the exit of the fuel cell as hydrogen was consumed, driving the shift reaction to consume the $\mathrm{CO}$ to the final mole fraction of 0.09 .

Water-gas shifting:

$\mathrm{CO}+\mathrm{H}_{2} \mathrm{O} \rightleftharpoons \mathrm{H}_{2}+\mathrm{CO}_{2} \quad\left(\Delta \mathrm{H}^{\circ}=-41 \mathrm{~kJ} / \mathrm{mol}\right)$

Hydrogen oxidation: 
$\mathrm{H}_{2}+\frac{1}{2} \mathrm{O}_{2} \rightarrow \mathrm{H}_{2} \mathrm{O}\left(\Delta \mathrm{H}^{\circ}=-286 \mathrm{~kJ} / \mathrm{mol}\right)$

Figure 3 also shows the resulting changes in carbon dioxide $\left(\mathrm{CO}_{2}\right)$, increasing from 0.120 at node 1 to approximately 0.310 at node 20 . Intuitively, the mole fraction gradient of $\mathrm{CO}_{2}$ was completely controlled by the $\mathrm{CO}$ mole fraction as well as the WGS kinetics. Thus, it reflected closely the CO conversion along the fuel channel.

As the results of both WGS and $\mathrm{H}_{2}$ oxidation in the fuel cell, higher $\mathrm{H}_{2}$ mole fraction at the entrance of the cell and lower $\mathrm{H}_{2}$ mole fraction at the end of the cell were observed. As shown in Figure 3, an initial increase in $\mathrm{H}_{2}$ mole fraction was evident between the first two nodes, from 0.291 to 0.334 , before decreasing through the remaining cell length. This suggested that there were strong impacts of WGS kinetics at the beginning of the cell, whereas the electrochemical activities had greater influence on the downstream path.

The change in $\mathrm{H}_{2}$ mole fraction was reflected by the change in water $\left(\mathrm{H}_{2} \mathrm{O}\right)$ mole fraction. As opposed to the maximum level of $\mathrm{H}_{2}$, the minimum $\mathrm{H}_{2} \mathrm{O}$ mole fraction (0.228) was observed at the same location shortly after the cell entrance. This was due to $\mathrm{H}_{2} \mathrm{O}$ consumption in WGS to yield $\mathrm{H}_{2}$ in the system, which also stimulated the remarkable decrease in $\mathrm{CO}$. Starting from node $2, \mathrm{H}_{2} \mathrm{O}$ mole fraction steadily increased to the highest level of 0.461 at the cell outlet as the hydrogen oxidation outweighed the effects of other reactions.

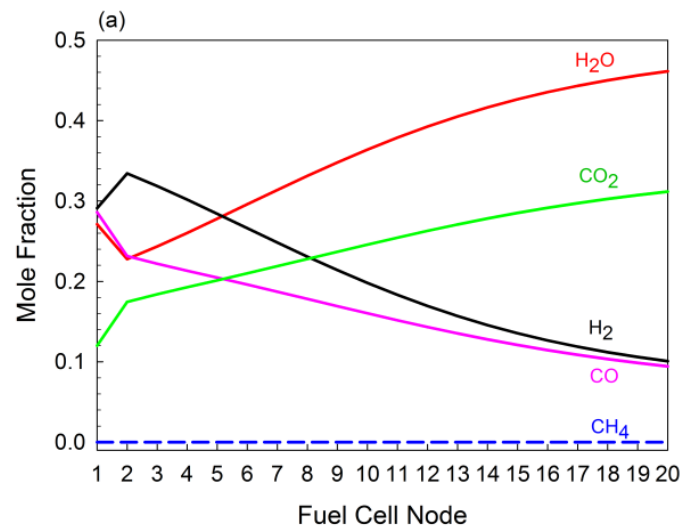

Figure 3: Distributed profiles of composition gradient in the anode at the initial steady state using syngas feed

The Nernst potential was quantified using an expression shown in Eq. 11. This function reveals that the Nernst potential is correlated to fuel cell temperature, as well as the partial pressure of $\mathrm{H}_{2}$ and $\mathrm{H}_{2} \mathrm{O}$ in the anode and $\mathrm{O}_{2}$ in the cathode. There is no significant change in $\mathrm{O}_{2}$ mole fraction in since the air mass flow rate in the cathode coming from the recuperated hybrid system is very high, so the effect of $\mathrm{O}_{2}$ on the Nernst potential transient is negligible. The $\mathrm{O}_{2}$ utilization was maintained very low, approximately at $19 \%$, with the maximum variation less than $3 \%$ over the entire course of experiment. In Eq. 11, the net value of the first term, which consists of the Gibbs free energy of water at the standard condition, is a positive value. Meanwhile, as the consequence of operating in excess water condition, the net value of the second term, as a function of temperature and component partial pressure is a negative value. In this case, there is a reversed effect of fuel cell temperature on the Nernst potential.

Nernst potential:

$V_{\text {Nernst }}=-\frac{\Delta G_{\mathrm{H}_{2} \mathrm{O}}^{\circ}}{2 F}+\frac{R_{u} T}{2 F} \ln \left[\frac{p_{\mathrm{H}_{2}} \cdot p_{\mathrm{O}_{2}}^{0.5}}{p_{\mathrm{H}_{2} \mathrm{O}}}\right]$ 


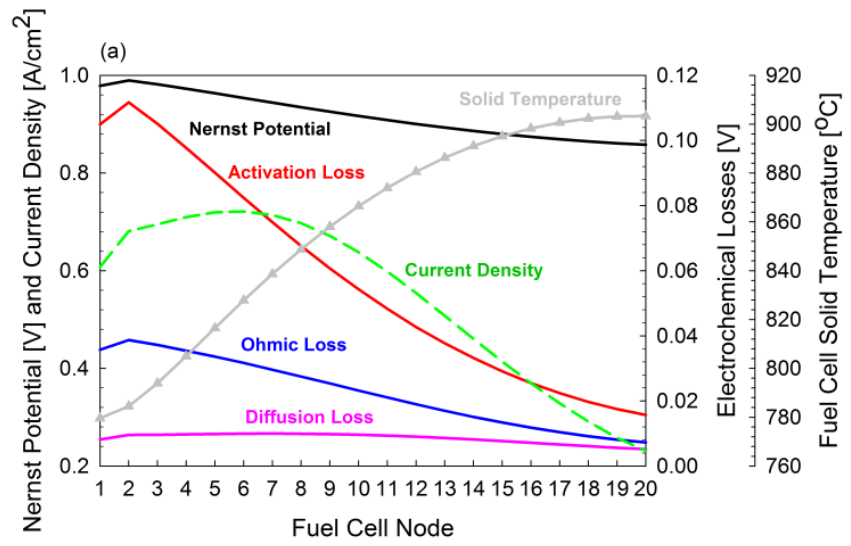

Figure 4: Nernst potential, current density, and electrochemical losses at the initial steady state using syngas feed

The corresponding effects on Nernst potential, current density, and polarization losses for a steady state with syngas feed are presented in Figure 4. Regardless of increased polarization losses at the entrance of the fuel cell, a $1 \%$ increase in Nernst potential from the initial condition was identified in the $\mathrm{H}_{2}$ concentrated region, as expected. Likewise, current density also increased significantly within the first two nodes. However, the highest current density (0.720) was found at around node 6.

The significant reduction in $\mathrm{H}_{2}$ partial pressure in the downstream region decreased Nernst potential by $13 \%$ to its lowest value at the cell outlet. This response was also influenced by the increasing fuel cell temperature. On the other hand, the electrochemical losses reduced substantially with the increasing temperature. The greater discrepancy in the transients between the Nernst potential and the electrochemical losses (increased voltage) eventually caused the significant decrease in current density (60\% from the inlet) at the cell outlet.

\subsection{Transient Analysis of Fuel Composition Change Impacts}

\subsubsection{Compositional Gradient and Localized Fuel Utilization}

The transient $\mathrm{CH}_{4}$ mole fraction profile after the step change in fuel composition is presented in Figure 5. Figure 5 shows that rapid conversion of $\mathrm{CH}_{4}$ occurred in the first six nodes. With respect to the selected initial conditions and the fuel cell configuration, the residence time of the fuel cell subsystem was on the order of hundreds of milliseconds (approximately $500 \mathrm{~ms}$ ), which was slower than the resolution of $1 \mathrm{~s}$ captured by the dynamic model used in this study. Zero to very low $\mathrm{CH}_{4}$ mole fraction was observed at approximately halfway down the fuel cell length immediately after the transient, approaching a complete $\mathrm{CH}_{4}$ conversion.

The analysis suggests that the behaviours in the fuel cell upstream would be strongly affected by the steam methane reforming (SMR) kinetics (Eq. 12) due to the observed significant variations. This reaction was initially stimulated by the elevated fuel cell thermal condition. Owing to the aggressive $\mathrm{CH}_{4}$ conversion in this region, the fuel cell solid temperature was expected to decrease in the long run, which would cause undesirable changes in the spatial temperature gradient and deceleration of the SMR kinetics.

The effects of reduced fuel cell solid temperature were clearly demonstrated by slower $\mathrm{CH}_{4}$ consumption at the end of the test. At the final state (at time 7,000 s), as presented in Figure 5b, the system exhibited a fairly distributed $\mathrm{CH}_{4}$ profile along the cell. The $\mathrm{CH}_{4}$ conversion was still incomplete until the fuel cell outlet. Overall, the result suggests that future control strategies of SOFC/GT hybrid system will need to include thermal management of fuel cell temperature.

Steam methane reforming:

$\mathrm{CH}_{4}+\mathrm{H}_{2} \mathrm{O} \rightleftharpoons 3 \mathrm{H}_{2}+\mathrm{CO}\left(\Delta \mathrm{H}^{\circ}=206 \mathrm{~kJ} / \mathrm{mol}\right)$ 

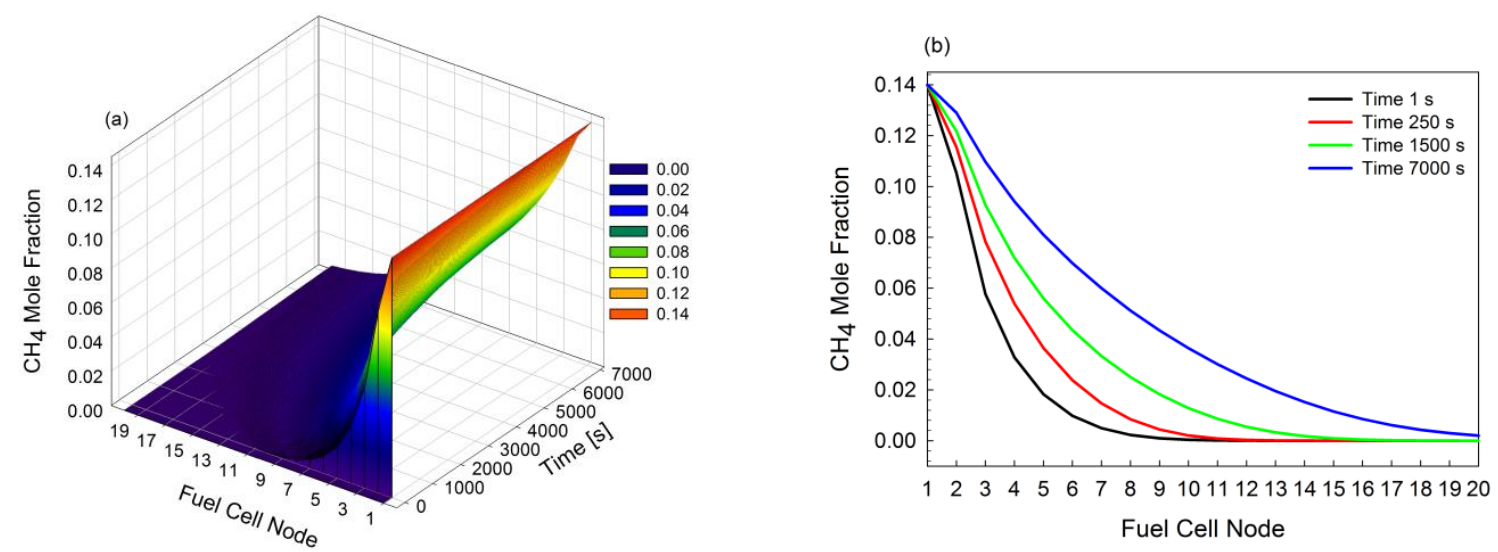

Figure 5: Variations in methane partial pressure, (a) a 3D mesh plot, as function of local position along the cell node and time, and (b) distributed profiles at time $1 \mathrm{~s}, 250 \mathrm{~s}, 1,500 \mathrm{~s}$, and 7,000 s after the step change

The profile of the CO composition gradient is shown in Figure 6. As shown in Figure 6, CO steeply increased to the highest point at node 7 and reduced at the end of the cell.

Changes in $\mathrm{CO}$ mole fraction gradient along the fuel cell length were highly reflected by the presence of $\mathrm{CH}_{4}$ in the system, as expressed in Eq. 12. The dramatic accumulation of $\mathrm{CO}$ in the fuel cell upstream (Figure 6b) was correspondingly promoted by the rapid consumption of $\mathrm{CH}_{4}$ (Figure 5b). The highest $\mathrm{CO}$ mole fraction was achieved when almost all $\mathrm{CH}_{4}$ was converted to SMR products. The complete $\mathrm{CH}_{4}$ consumption subsequently initiated the depletion in $\mathrm{CO}$ in the downstream region, which was due to WGS reactions (Eq. 9).

However, the maximum CO reduced by about half and shifted to node 16 within 7,000 s. The shift of the maximum $\mathrm{CO}$ from node 7, 35\% from the inlet, downstream to node 16 at 7,000 s was strongly motivated by the reduction of cell temperature. As the test progressed, decreasing fuel cell solid temperature decreased SMR kinetics. This ultimately reduced the formation of $\mathrm{CO}$, and thus, moved the region of high $\mathrm{CO}$ concentration to the end of the fuel cell.
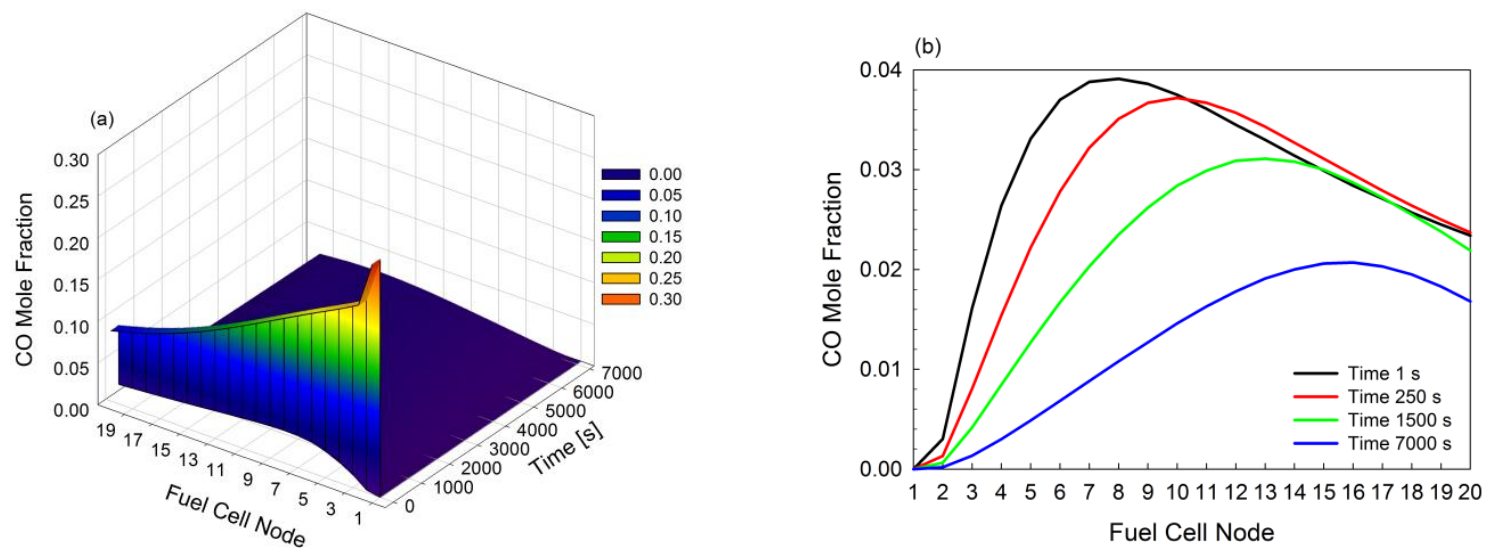

Figure 6: Transient response of carbon monoxide composition, (a) a 3D mesh plot, as function of local position along the cell node and time, and (b) Distributed profiles at time $1 \mathrm{~s}, 250 \mathrm{~s}, 1,500 \mathrm{~s}$, and 7,000 s after the step change

The change in the $\mathrm{H}_{2}$ content over the entire course of the experiment is shown in Figure 7. The coupled effects from WGS, $\mathrm{H}_{2}$ oxidation as well SMR, as shown in Eq. 9, Eq. 10, and Eq. 12, have determining influence on the $\mathrm{H}_{2}$ mole fraction profile. The initial transient increased in $\mathrm{H}_{2}$ mole fraction in the first half of the cell length followed closely the dramatic reformation of methane. As the result of the high production of $\mathrm{H}_{2}$ as well as the decreasing SMR kinetics and WGS reaction, the impact of $\mathrm{H}_{2}$ oxidation became more noticeable in the second half region. Within this region, $\mathrm{H}_{2}$ was consumed faster than its formation. As such, significant reduction in $\mathrm{H}_{2}$ mole fraction level was observed. Theoretically, increasing $\mathrm{H}_{2}$ consumption should have shifted the equilibrium of WGS process further to product side, and so moderating the $\mathrm{H}_{2}$ reduction. However, this effect was insignificant due to diminishing $\mathrm{CH}_{4}$ content that restricted $\mathrm{CO}$ generation from methane reforming.

Due to the corresponding effects of SMR on the fuel cell solid temperature over 7,000 s time studied, the local maximum of $\mathrm{H}_{2}$ mole fraction gradually shifted to the end of the cell to a lower level (0.220), featuring a more even distribution curve. It is also interesting to note that the $\mathrm{H}_{2}$ concentration at the exit was effectively the same during the entire transition, despite the shifting internal profiles. This illustrates the usefulness of a model 
which can predict shifting internal profiles that could not otherwise be detected by experiment since spatial measurements are very difficult to obtain inside the SOFC.
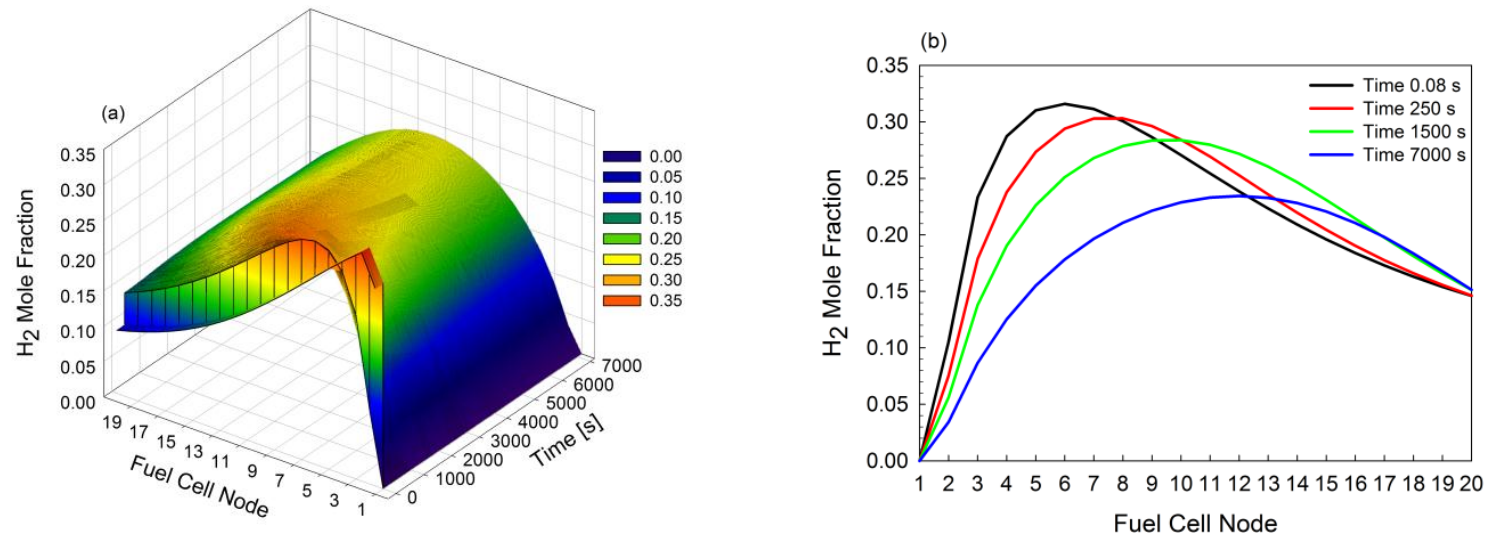

Figure 7: Hydrogen mole fraction gradient, (a) a 3D mesh plot, as function of local position along the cell node and time, and (b) distributed profiles at time $1 \mathrm{~s}, 250 \mathrm{~s}, 1,500 \mathrm{~s}$, and 7,000 s after the step change

The corresponding change in $\mathrm{H}_{2} \mathrm{O}$ mole fraction is illustrated in Figure 8. As shown in Figure 8, the resulting variations in $\mathrm{H}_{2} \mathrm{O}$ mole fraction were inversely correlated to $\mathrm{H}_{2}$ dynamic response (Figure 7). Substantial reduction in $\mathrm{H}_{2} \mathrm{O}$ partial pressure was more apparent at the beginning of the cell, between node1 to node 6 , following the rapid methane reformation and WGS reactions. Similarly, the shifting in the local minimum points of $\mathrm{H}_{2} \mathrm{O}$ was attributed to the effect of slower methane conversion indicated in Figure 5 . Significant formation of $\mathrm{H}_{2} \mathrm{O}$ due to electrochemical reactions was identified at node 6 onwards when $\mathrm{H}_{2} \mathrm{O}$ mole fraction started to increase up to its final level at the fuel cell outlet. Over 7,000 s, the final $\mathrm{H}_{2} \mathrm{O}$ mole fraction at the fuel cell exit was about 0.740 , slightly lower than the inlet mole fraction $(0.860)$.
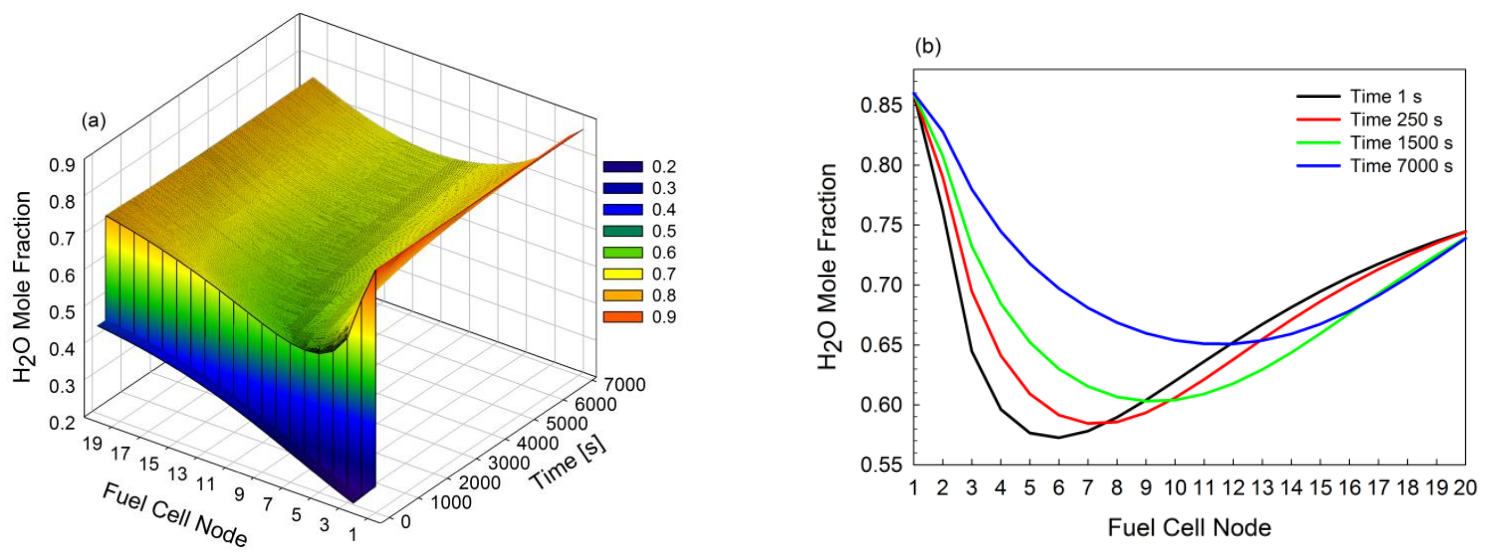

Figure 8: Water mole fraction gradient, (a) a 3D mesh plot, as function of local position along the cell node and time, and (b) distributed profiles at time $1 \mathrm{~s}, 250 \mathrm{~s}, 1,500 \mathrm{~s}$, and 7,000 s after the step change

\section{Fuel Utilization}

The changes in localized fuel utilization in response to fuel composition transition are shown in Figure 9. Localized fuel utilization, $U_{f}$, for each node across the fuel cell length is defined in Eq. 13, where $x_{i}$ is the partial pressure for fuel component $i, j$ represents a current node, while $j+1$ represents the exit of the current node. As can be seen in Figure 9a, fuel utilization at the initial steady state was almost uniformly distributed across the cell but with a lower level at both cell inlet (node 1) and outlet (node 20). After switching the anode feed to humidified methane, the highest peaks were found at node 2 at $1 \mathrm{~s}$, and at node 19 after 7,000 s (Figure 9b). The highest fuel utilization at the beginning of the cell at the initial transition phase was likely due to rapid SMR reaction that led to significant variations in localized $\mathrm{H}_{2}$ availability. Intuitively, this was promoted by the elevated initial fuel cell solid temperature.

$U_{F}(j)=\frac{x_{H_{2}}(j+1)+x_{C O}(j+1)+4 x_{C H_{4}}(j+1)}{x_{H_{2}}(j)+x_{C O}(j)+4 x_{C H_{4}}(j)}$ 
At the beginning of the cell, fuel utilization reduced gradually over the course of the experiments, but these dynamics were reversed at the end of the cell. The analysis indicates that the variations at the beginning of the cell were significantly driven by the reduction of fuel cell temperature, which was also reflected by the reduction in $\mathrm{CH}_{4}$ consumption over time studied. Meanwhile, as methane was almost completely consumed at the downstream region, the trends of fuel utilization were strongly related to the activities of electrochemical reactions.

At the end of the cell, fuel utilization increased over time with increasing current density and less available fuel. This is clearly illustrated because the hydrogen concentration in the last half of the cell was not significantly changing, as seen in Figure 7, while current density was increasing at the end of the cell. The overall fuel utilization increased from $67 \%$ to approximately $71 \%$ as fuel was switched to humidified methane and remained constant until the test was terminated.
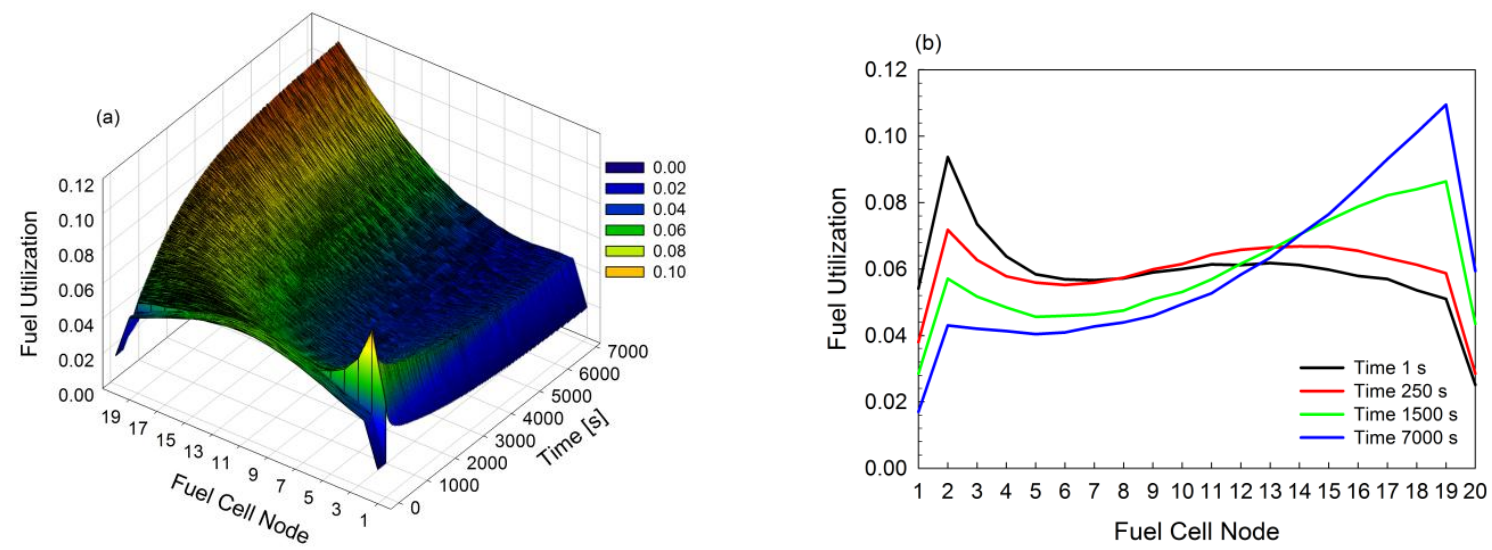

Figure 9: Localized fuel utilization, (a) a 3D mesh plot, as function of local position along the cell node and time, and (b) distributed profiles at time $1 \mathrm{~s}, 250 \mathrm{~s}, 1,500 \mathrm{~s}$, and 7,000 s after the step change

\subsection{Current Density, Nernst Potential, and Electrochemical Losses}

\section{Current Density}

The local current density profiles are illustrated in Figure 10. As the result of switching the fuel to humidified methane at a constant fuel cell load, higher current density was observed at the end of the cell, as opposed to the profile at the initial steady state of syngas operation (Figure 10a).

As shown in Figure 10b, at $1 \mathrm{~s}$ after the transient, current density increased to the highest value $(0.73)$ at around node $8,40 \%$ of the cell length, before slowly decreasing through the remaining fuel cell length. However, decreasing solid temperature over $7,000 \mathrm{~s}$ test subsequently shifted the maximum current density towards the end of the cell, resulting in the highest peak $(0.83)$ at node 18 . The distributed profile at the end of the test was mirrored the performance at the initial steady state.

The dynamics of current density were greatly coupled with the effects of $\mathrm{H}_{2}$ partial pressure and Nernst potential. As expected, higher current density region was achieved in the elevated solid temperature segments (Figure 15) at a relatively higher partial pressure of $\mathrm{H}_{2}$ (Figure 5), as well as higher Nernst potential (Figure 11). Increasing current density at the end of the cell also promoted the fuel cell heat generation, as indicated in Figure 20. 

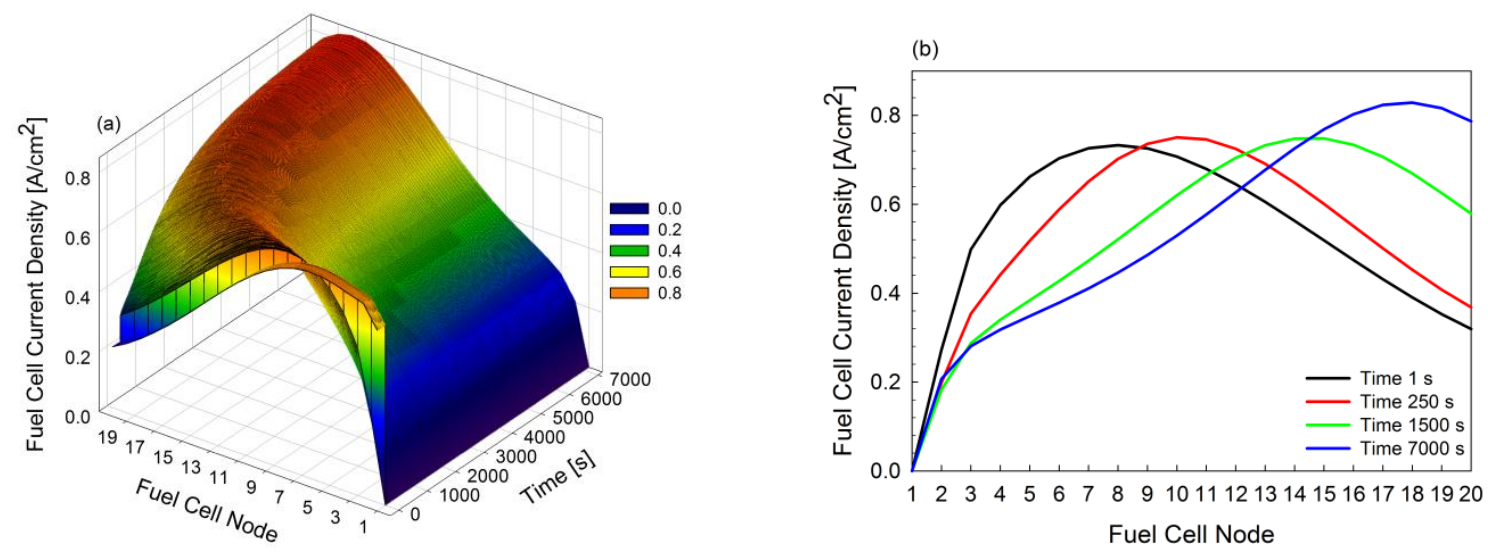

Figure 10: Local current density, (a) a 3D mesh plot, as function of local position along the cell node and time, and (b) distributed profiles at time $1 \mathrm{~s}, 250 \mathrm{~s}, 1,500 \mathrm{~s}$, and 7,000 s after the step change

\section{Nernst Potential}

The resulting variation in Nernst potential is plotted in Figure 11. Over 7,000 s, a rapid increase in Nernst potential with insignificant variations with time was observed at the beginning of the cell, as illustrated in Figure $11 \mathrm{~b}$. This was due to dramatic increase in the $\mathrm{H}_{2}$ mole fraction to $31 \%$ (Figure 7), which was also correlated to evenly distributed profiles in the local solid temperature gradient over time (Figure 15), and a $30 \%$ reduction in $\mathrm{H}_{2} \mathrm{O}$ (Figure 8).
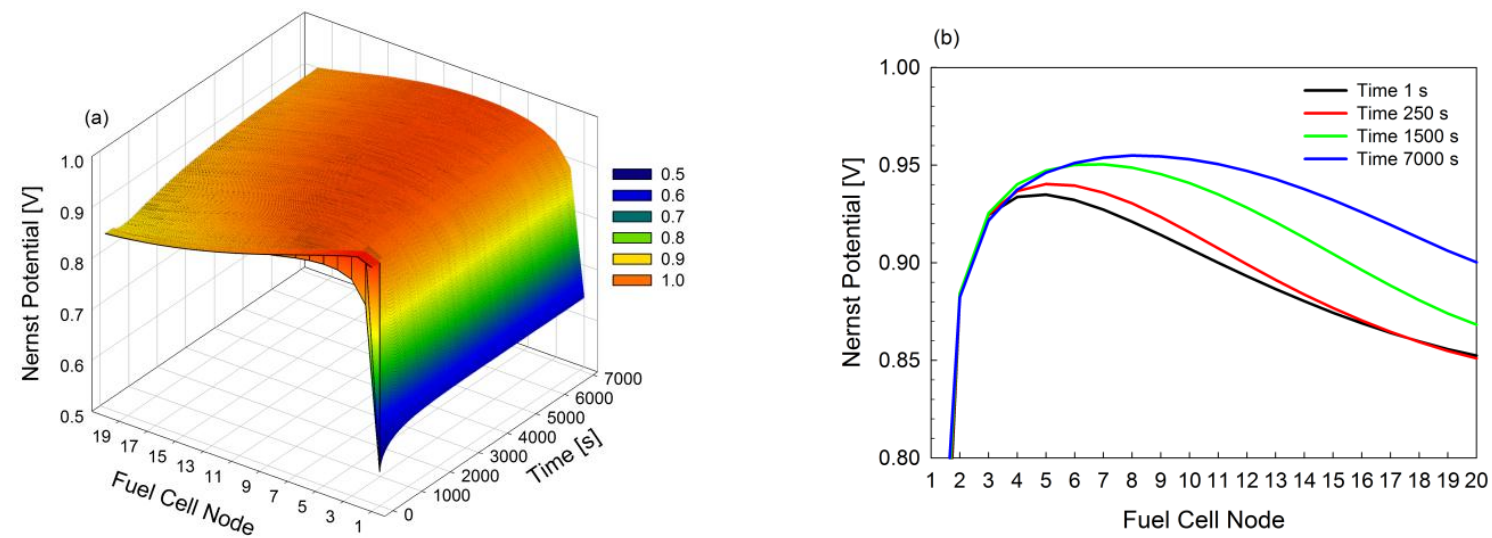

Figure 11: Nernst potential distribution, (a) a 3D mesh plot, as function of local position along the cell node and time, and (b) distributed profiles at time $1 \mathrm{~s}, 250 \mathrm{~s}, 1,500 \mathrm{~s}$, and 7,000 s after the step change

Meanwhile, the Nernst potential dynamics in the second half of the cell was most likely influenced by the fuel cell temperature changes rather than the partial pressures of $\mathrm{H}_{2}$ and $\mathrm{H}_{2} \mathrm{O}$. As presented in Figures 7 and 8 , the $\mathrm{H}_{2}$ and $\mathrm{H}_{2} \mathrm{O}$ contents did not change significantly. Although the $\mathrm{H}_{2}$ mole fraction reduced over the time studied, the Nernst potential of the cell increased with decreasing fuel cell temperature. Over 7,000 s, the peaks of the Nernst potential were scattered between node 5 and node 8 (20\% to $40 \%$ of the cell length) from approximately $0.93 \mathrm{~V}$ to $0.96 \mathrm{~V}$.

\section{Electrochemical Resistance}

The variations in activation loss in response to the fuel composition change are shown in Figure 12. The activation loss represents the polarization resistance due to the required activation energy to initiate electrochemical reactions [24]. In this test, as presented in Figure 12b, the cell initially exhibited a very low activation resistance at node 1 in the absence of $\mathrm{H}_{2}$ molecules. But, it steeply increased with time to a higher resistance at around node 4 to node 8 ( $20 \%$ to $40 \%$ from the fuel cell inlet), followed by a steady decrease to the outlet shortly after the maximum point.

The analysis indicates that higher activation loss was obtained at higher $\mathrm{H}_{2}$ partial pressure (Figure 7), current density (Figure 10), and Nernst potential (Figure 11). As expected, the significant reduction in fuel cell temperature over 7,000 s test substantially increased activation loss. However, it was expected that the influence of partial pressure changes was greater than the impacts of temperature in determining the activation loss at the beginning of the cell. 

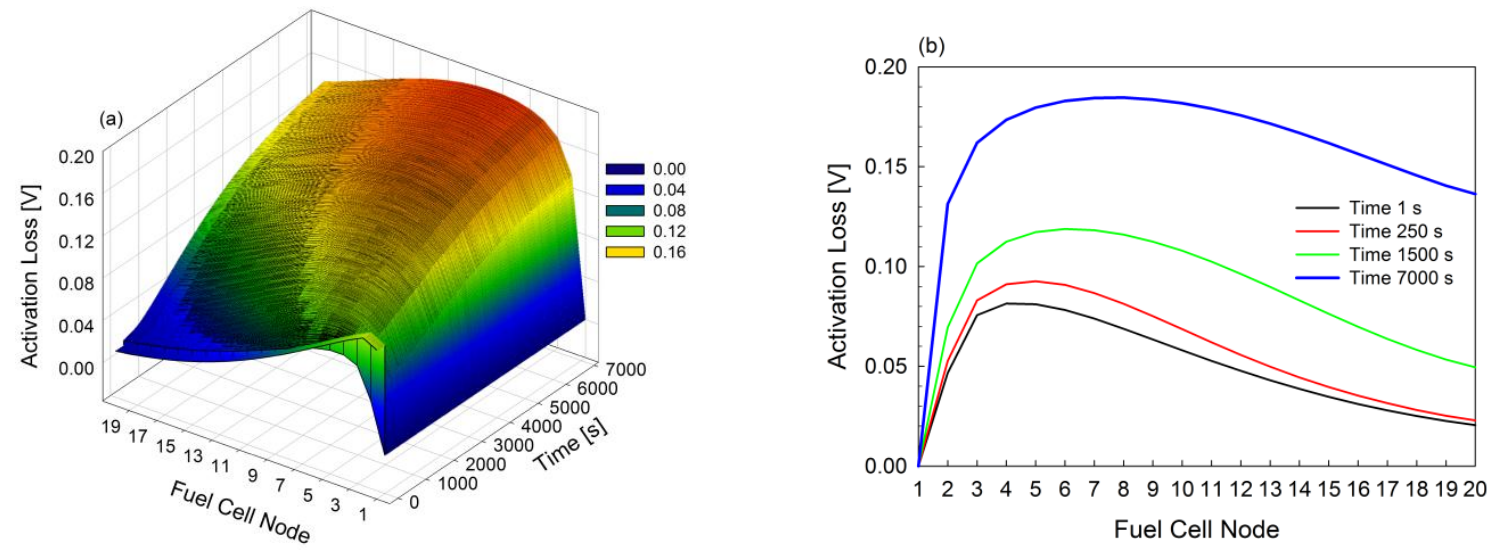

Figure 12: Activation loss distribution, (a) a 3D mesh plot, as function of local position along the cell node and time, and (b) distributed profiles at time $1 \mathrm{~s}, 250 \mathrm{~s}, 1,500 \mathrm{~s}$, and 7,000 s after the step change

As shown in Figure 13 due to similar correlation to fuel cell temperature, changes in ohmic loss closely followed the trend observed in activation loss distribution. Figure 13b shows that over the entire course of the transient, ohmic loss increased with the decreasing fuel temperature. Overall, the distributed ohmic resistance varied between $0.01 \mathrm{~V}$ to $0.057 \mathrm{~V}$ with respect to the variations in the fuel cell temperature, approximately between $660{ }^{\circ} \mathrm{C}$ to $900{ }^{\circ} \mathrm{C}$.
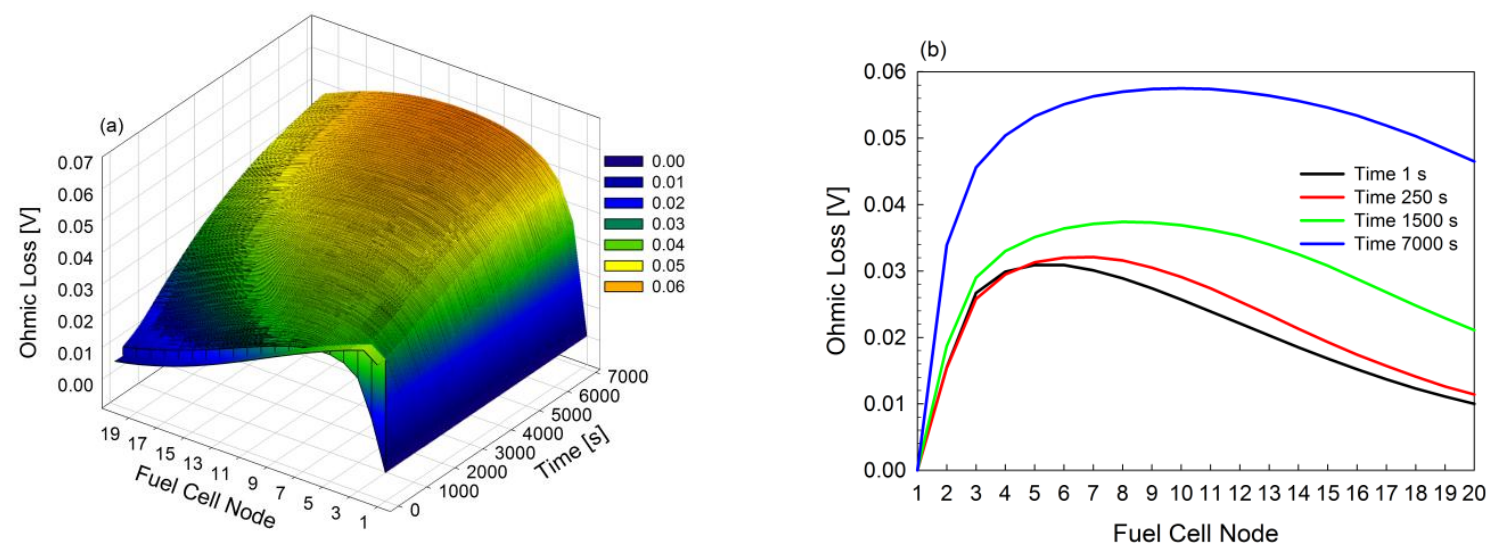

Figure 13: Ohmic loss profile, (a) a 3D mesh plot, as function of local position along the cell node and time, and (b) distributed profiles at time $1 \mathrm{~s}, 250 \mathrm{~s}, 1,500 \mathrm{~s}$, and 7,000 s after the step change

The transient response of diffusion loss is shown in Figure 14. Theoretically, this loss results from the resistance associated with the transportation of chemical compounds to the reaction sites [24]. Intuitively, diffusion loss is strongly correlated to the mole fraction gradients across the cell. However, variations in the local current density and the fuel cell temperature also contribute some impacts on the changes in this polarization resistance.

In comparison to other polarization resistance, the diffusion loss had the least impact on the fuel cell, since a thin electrode was used. Overall, over 7,000 s of test, the system started at very low diffusion resistance at the cell inlet, and sharply increased at node 2, as shown in Figure 14b. The diffusion loss at node 2 increased with time, reflecting the increase in localized $\mathrm{H}_{2} \mathrm{O}$ mole fraction or the reduction in $\mathrm{H}_{2} \mathrm{O}$ consumption (Figure 8) when the fuel cell solid temperature dropped. Toward the end of the test, the increase at node 2 was more significant, with a substantial decrease immediately after node 2.

In the first $250 \mathrm{~s}$ of the transient, the maximum diffusion resistance was demonstrated at node 10 , and gradually shifted to the cell exit to higher values over 7,000 s. Without significant variation in $\mathrm{H}_{2} \mathrm{O}$ mole fraction, the diffusion loss at the end of the cell increased with decreasing fuel cell temperature, and increasing current density (Figure 10). 

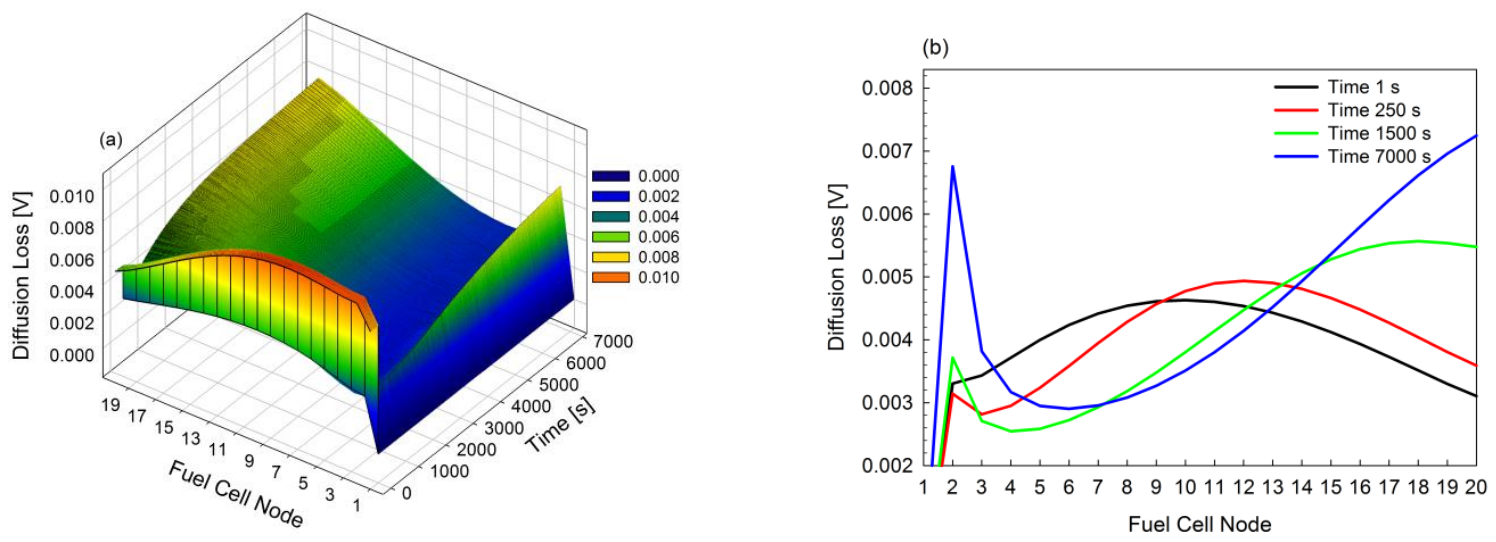

Figure 14: Transient profile of diffusion loss, (a) a 3D mesh plot, as function of local position along the cell node and time, and (b) distributed profiles at time $1 \mathrm{~s}, 250 \mathrm{~s}, 1,500 \mathrm{~s}$, and 7,000 s after the step change

\subsubsection{Fuel Cell Thermal Performance}

\section{Solid Temperature}

The result of solid temperature distribution is presented in Figure 15. During the initial steady state, as shown before time $0 \mathrm{~s}$ in Figure 15a, the solid temperature inclined from node 1 to node 20, in a range of $780{ }^{\circ} \mathrm{C}$ at the inlet, to $903{ }^{\circ} \mathrm{C}$ at the outlet, with an average temperature of $857{ }^{\circ} \mathrm{C}$. This resulted from an initial operating temperature of $800{ }^{\circ} \mathrm{C}$ using coal-derived syngas feed. In response to the fuel composition switch, the local solid temperature decreased significantly afterwards, except just a slight increase at the cell outlet during the first few minutes after the transient.

The slight increase in the solid temperature at the end of the cell occurred at the first $250 \mathrm{~s}$ is clearly illustrated in Figure 15b. This dynamic was driven by the increase in fuel utilization (Figure 9), current density (Figure 10), and heat generation (Figure 19). In a short-term period, due to the large heat capacity of the fuel cells, the increase in fuel cell temperature was not offset by the temperature reduction promoted by the steam methane reforming reactions.
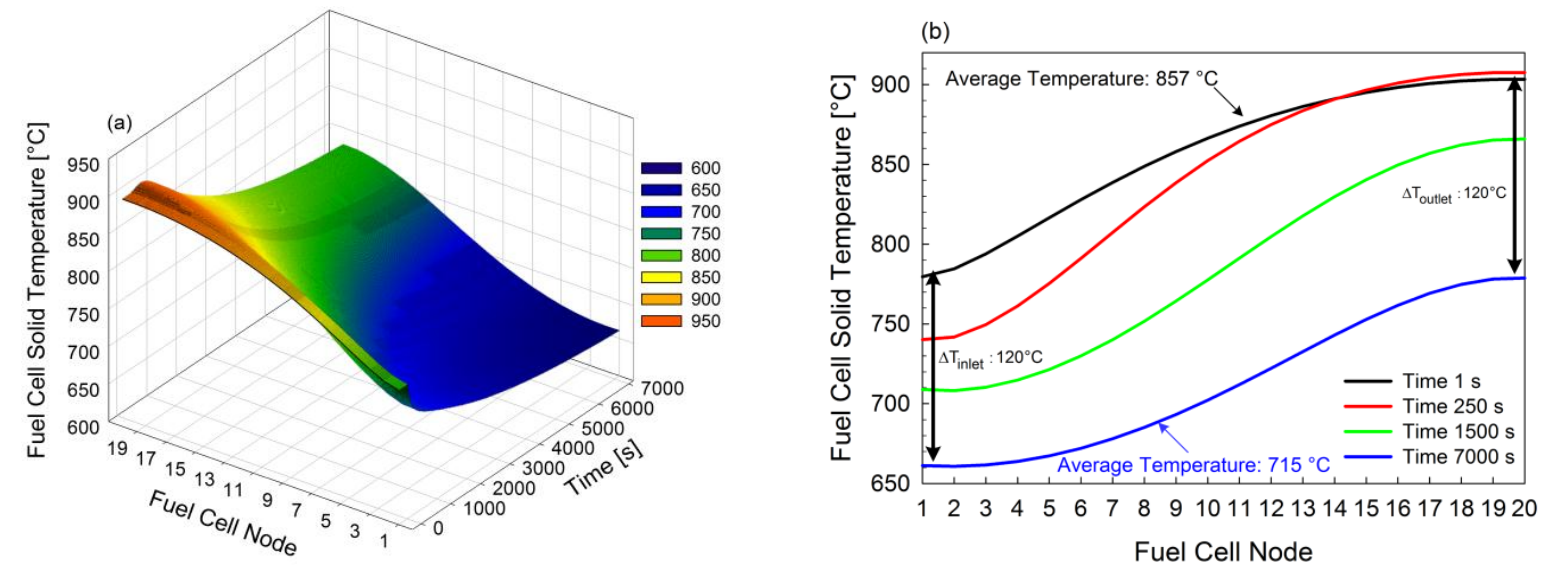

Figure 15: The dynamic profiles of fuel cell temperature, (a) a 3D mesh plot, as function of local position along the cell node and time, and (b) distributed profiles at time $1 \mathrm{~s}, 250 \mathrm{~s}, 1,500 \mathrm{~s}$, and 7,000 s after the step change

Unlike the end of the cell, the substantial reduction in solid temperature at the beginning of the cell was highly correlated to the drastic localized methane reforming as indicated in Figure 5, and heat flux, as reflected by the solid-gas temperature difference in Figure 20. As the consequence, 33\% of the total temperature change at the cell entrance region took place in $250 \mathrm{~s}$ after the transient, and about $60 \%$ temperature drop occurred within the first $1,500 \mathrm{~s}$ (Figure 15b). This cooling impact was remarkable even though there was a $2 \%$ decrease in cathode air mass flow during the first 1,500 s of test (Figure 16), which should have mitigated the impact on the solid temperature. Due to the control action taken by the system to maintain constant turbine speed at 40 , $500 \mathrm{rpm}$, a $40 \%$ increase in turbine load caused a $1 \%$ increase in compressor discharge pressure. This resulted in a $4 \%$ reduction of compressor inlet flow which eventually reduced the cathode air flow by $2 \%$ [30]. 


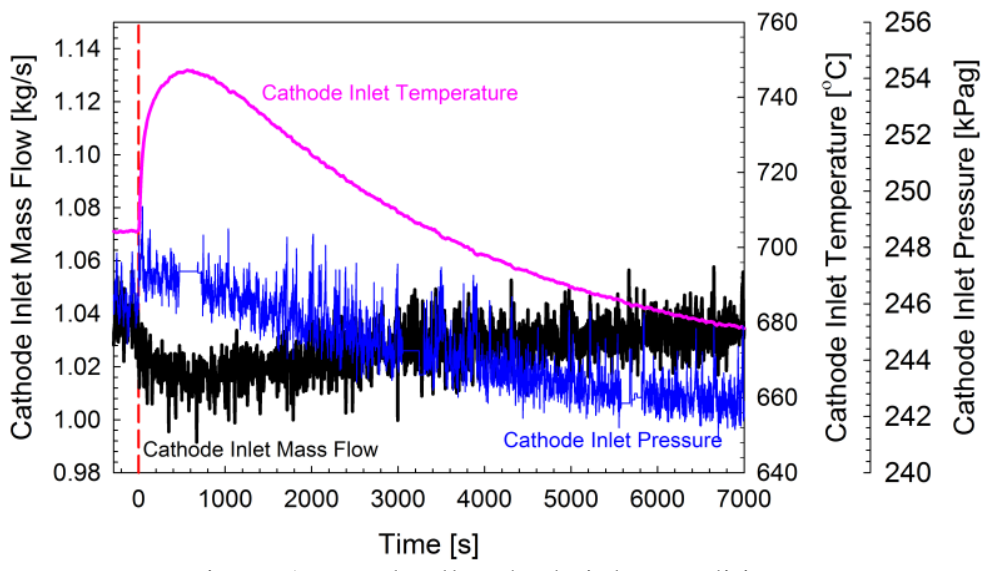

Figure 16: Fuel cell cathode inlet conditions

As presented in Figure 15b, despite the small temperature changes observed around the first and the last few nodes, the solid temperature across the cell increased to the maximum temperature region near the outlet. The increase in solid temperature occurred in the downstream region where $\mathrm{CH}_{4}$ mole fraction was almost complete, while significant $\mathrm{H}_{2}$ oxidation was observed. Hence, it resulted in less heat consumption in the reforming reaction. In addition, higher current density was also localized at the downstream region.

As the test progressed, the cell exit eventually cooled off to the point where the new steady state temperature profile was identical to the initial steady state profile (i.e. before fuel composition switch), but at a lower average temperature $\left(715{ }^{\circ} \mathrm{C}\right)$. Decreasing the solid temperature decelerated the SMR kinetics that ultimately led to a more gradual $\mathrm{CH}_{4}$ conversion. At the end of the test, the fuel cell temperature was distributed more evenly between $661{ }^{\circ} \mathrm{C}$ at node 1 , and $778{ }^{\circ} \mathrm{C}$ at node 20 . Due to shifted localized SMR towards the end of the cell, greater temperature reduction occurred at the cell outlet between time 1,500 s and 7,000 s. However, after $7,000 \mathrm{~s}$, the fuel cell temperature difference between the initial and the final steady state at the cell inlet was about 120 degrees, similar to that observed at the cell exit.

Figure 17 presents the relevant solid temperature gradient between fuel cell nodes, $d T / d x$, for selected critical nodes. For control system development, fuel cell temperature gradient is a critical control variable because uneven temperature changes across the fuel cell length during transient processes can lead to dramatic localized thermal stress on the material, which contributes to fuel cell material destruction. As the result of the initial average temperature of $857{ }^{\circ} \mathrm{C}$ with a $113{ }^{\circ} \mathrm{C}$ temperature difference across the cell before the fuel composition change, the maximum $d T / d x$ of $11.5 \mathrm{~K} / \mathrm{cm}$ occurred at node $5,25 \%$ down the cell inlet. The maximum temperature gradient remained at the same location over $100 \mathrm{~s}$ after the step change, featuring an increasing value up to $15.8 \mathrm{~K} / \mathrm{cm}$. Unfortunately, over the $7,000 \mathrm{~s}$ test period, the greatest change in the localized fuel cell temperature of $16 \mathrm{~K} / \mathrm{cm}$ was indicated at node 7, $250 \mathrm{~s}$ after the fuel transition. The highest peak of $d T / d x$ was then shifted node by node towards the cell outlet as the test continued. However, beyond $3,100 \mathrm{~s}$, the maximum $d T / d x$ remained at node 13 , with a lower final value $(10 \mathrm{~K} / \mathrm{cm})$ at the end of the test.

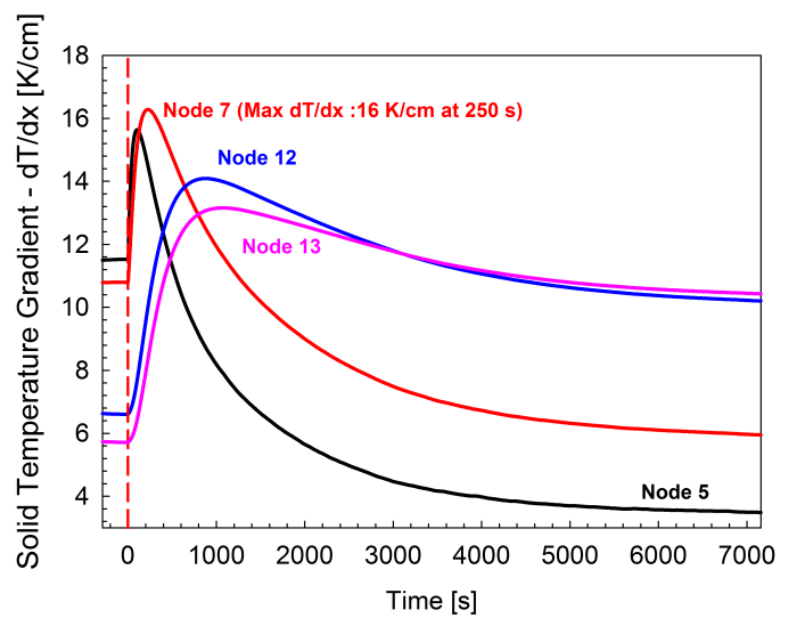

Figure 17: Spatio-fuel cell temperature gradient, $d T / d x$ 
The profile of average solid temperature in Figure 18a shows that there was a gradual change over the $7,000 \mathrm{~s}$ test period. Meanwhile, Figure $18 \mathrm{~b}$ illustrates that the most extreme transient in average solid temperature gradient as a function of time, $d T_{\text {ave }} / d t$, was not more than $0.10 \mathrm{~K} / \mathrm{s}$.
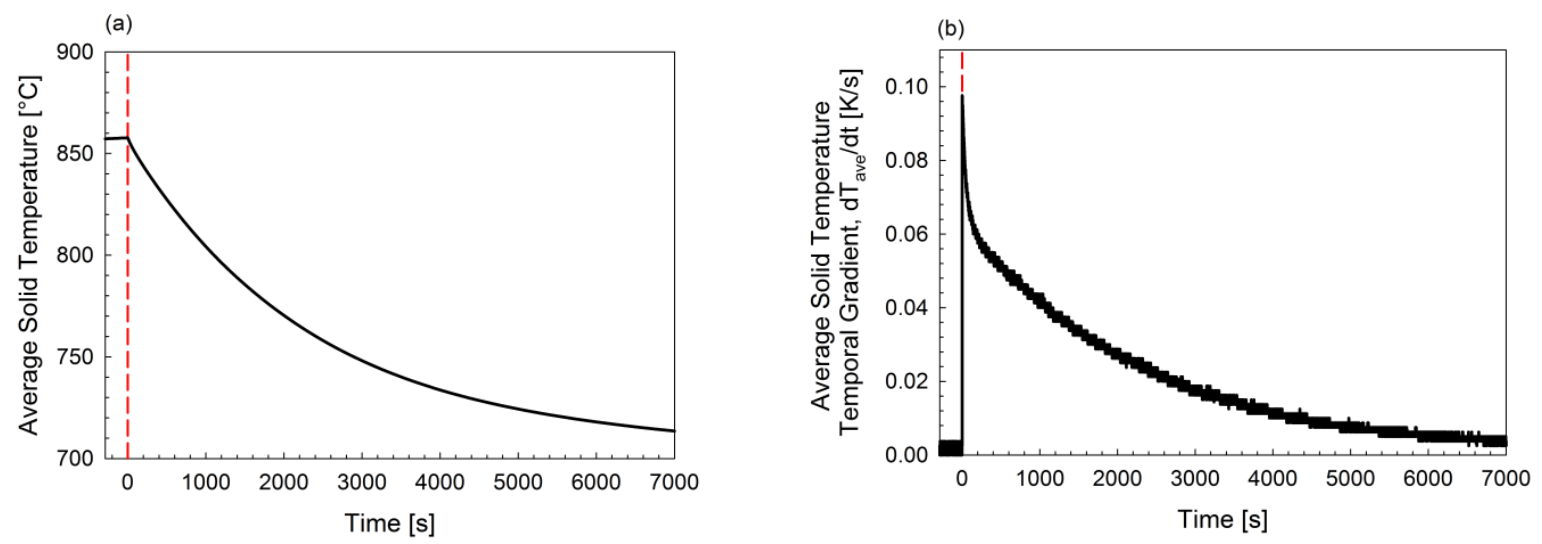

Figure 18: Average solid temperature profile, (a) Average solid temperature profile as a function of time, and (b) Temporal changes of Average solid temperature, $d T_{a v e} / d t$

\section{Cathode Gas Temperature}

The associated dynamic response in the gas temperature is highlighted in Figure 19. Overall, the profile of cathode gas temperature features gradual decay characteristics toward its final value, with a slight increase at the cell outlet within the first few minutes, similar to the fuel cell solid temperature trends. However, as shown in Figure 19a, the cathode gas temperature at the fuel cell inlet did not follow the drastic decrease observed in the solid temperature (Figure 15a). In contrast, the profile of cathode gas temperature at the cell entrance was dominated by the $40{ }^{\circ} \mathrm{C}$ increase in cathode inlet air temperature (Figure 17) over the first $600 \mathrm{~s}$ after the initiation of the fuel composition change, due to the integrated system effects on the gas turbine system.
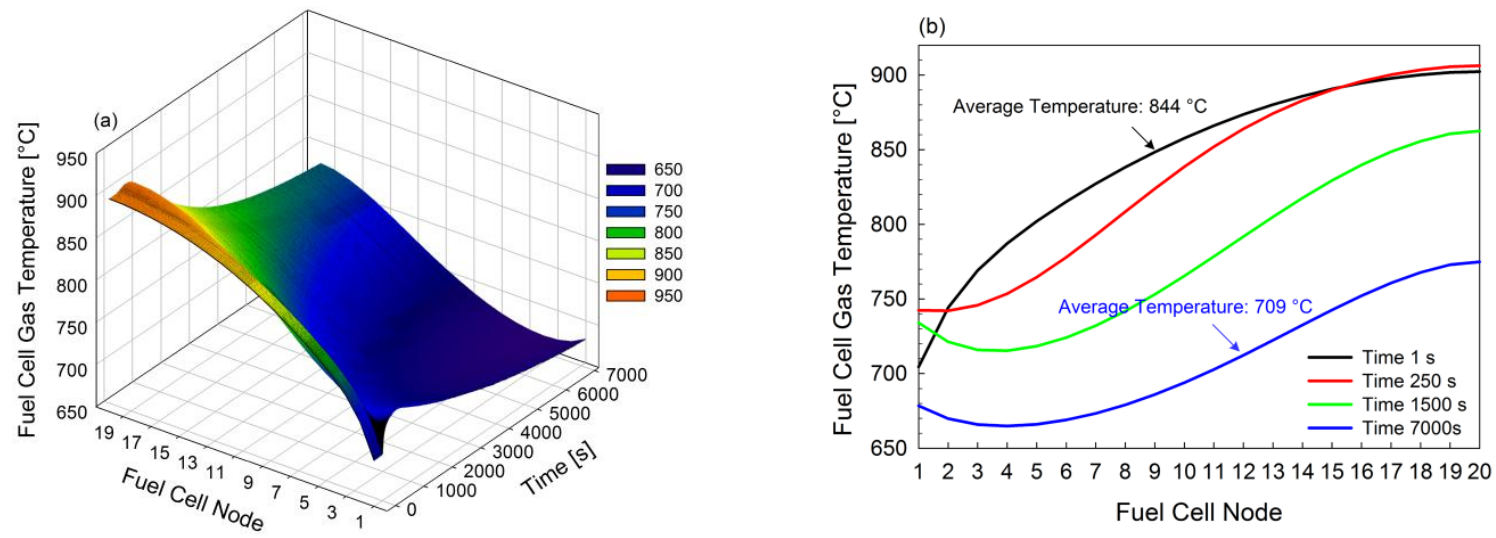

Figure 19: Cathode gas temperature profiles, (a) a 3D mesh plot, as function of local position along the cell node and time, and (b) distributed profiles at time $1 \mathrm{~s}, 250 \mathrm{~s}, 1,500 \mathrm{~s}$, and 7,000 s after the step change

As depicted in Figure 19b, the cathode gas temperature at the initial steady state monotonically increased from $704{ }^{\circ} \mathrm{C}$ at node 1 to $902{ }^{\circ} \mathrm{C}$ at the last node, approaching a $200^{\circ} \mathrm{C}$ difference across the cell. After the fuel transition, an increasing gas temperature towards the end of the cell was locally distributed in S-shaped curves with the lowest temperature observed at around nodes 4 and 5. Correspondingly, over 7,000 s, the changes in gas temperature closely followed the distribution of fuel cell solid temperature. The detailed analysis suggests that the dynamic response at the beginning of the fuel cell was driven by the heat flux, unlike the changes occurred at the exit of the cell. At the final state, gas temperature difference across the cell length reduced by about $50 \%$ with the decreasing local gas temperature, in comparison to the initial steady state.

\section{Heat Generation}

The dynamic trajectory of heat generation in the fuel cell unit per given length of each node is shown in Figure 20. As the consequence of operating the fuel cell at 220 A total current with $67 \%$ fuel utilization using syngas, a maximum of $17 \mathrm{~W} / \mathrm{cm}$ of heat was generated at the inlet, decreasing to a minimum of $3 \mathrm{~W} / \mathrm{cm}$ at the 
outlet (Figure 20a). More heat was accumulated in the region in which contained higher current density (Figure 4), as expected.
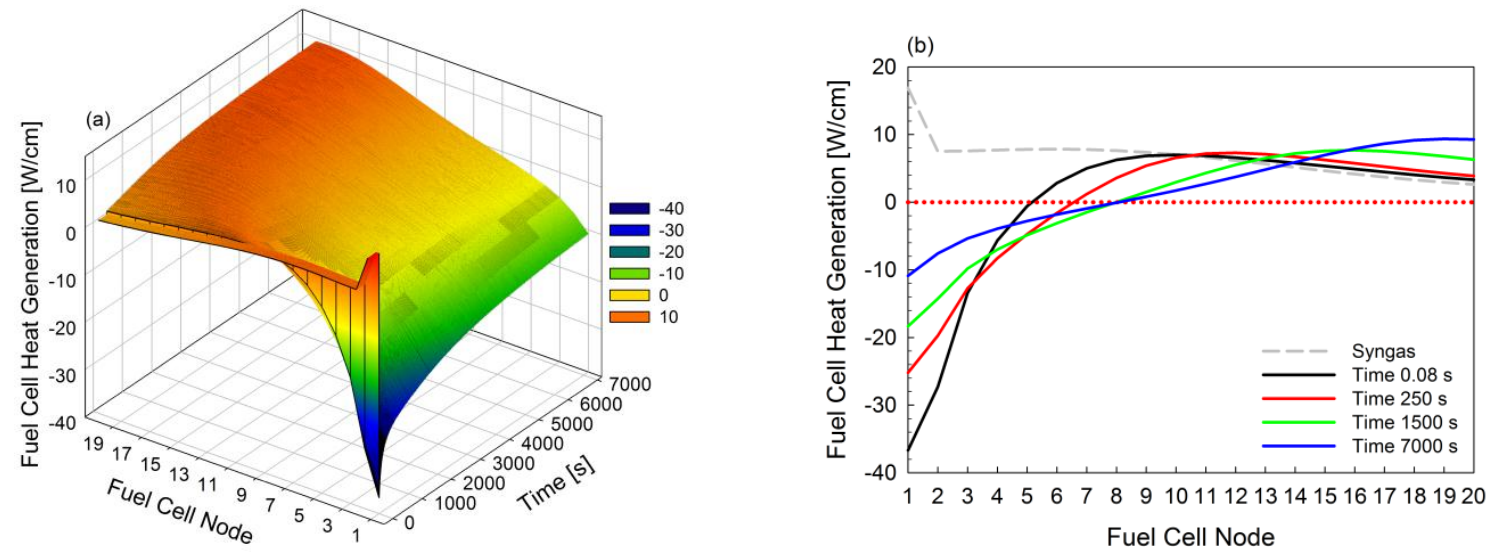

Figure 20: Fuel cell heat generation, (a) a 3D mesh plot, as function of local position along the cell node and time, and (b) distributed profiles at time $1 \mathrm{~s}, 250 \mathrm{~s}, 1,500 \mathrm{~s}$, and 7,000 s after the step change

After shifting the syngas feed to methane-rich gas, a detrimental reduction in heat generation was evident at the beginning of the cell, resulting in an immediate drop of $53 \mathrm{~W} / \mathrm{cm}$ at the first node from $17 \mathrm{~W} / \mathrm{cm}$ at the initial state to a $-36 \mathrm{~W} / \mathrm{cm}$ at $1 \mathrm{~s}$ after the step change. But, heat generation increased gradually towards the maximum region at the fuel cell downstream.

The coupled effects of the sudden decrease in the fuel cell heat generation at the cell inlet (Figure 20) were reflected by the remarkable reduction in solid temperature (Figure 15). This change was due to higher heat consumption in the highly endothermic methane reformation at the cell upstream when the system was fed by $14 \%$ methane. Meanwhile, as the highly exothermic $\mathrm{H}_{2}$ oxidation significantly took place in the second half of the cell length, the solid temperature started to increase, as shown in Figure 15.

In a longer experimental run, the contribution of deceleration in steam methane reforming was demonstrated clearly at the cell entrance, in which heat generation at the first node increased gradually with decreasing rate in methane conversion. Beyond more than 7,000 s after the step change, the heat generation across the cell moderately fluctuated, but its highest peak shifted from the centre to the end of the cell.

\section{Solid-Gas Temperature Difference}

The fuel cell thermal performance was further analyzed by quantifying the local temperature difference between solid and cathode gas temperatures $\left(T_{\text {solid }}-T_{\text {gas }}\right)$, as provided in Figure 21 . The local and the overall temperature difference are shown in Figure 21a and 21b respectively. As shown in Figure 21a, the profile of temperature difference in the first half of the cell length was quite distinct from the dynamic response in the second half of the cell, indicating appreciable changes in the beginning of the cell, and insignificant transient response at the end of the cell. Variations of temperature difference at the cell exit were between $1^{\circ} \mathrm{C}$ to $10^{\circ} \mathrm{C}$ over $7,000 \mathrm{~s}$.

At the initial transient period that is denoted as time $0.08 \mathrm{~s}$ in Figure 20a, the temperature difference reduced dramatically by about $80 \%$, from $75{ }^{\circ} \mathrm{C}$ to $14.5^{\circ} \mathrm{C}$, within the first 5 nodes (25\% of the cell length), following by a slow decrease to $1{ }^{\circ} \mathrm{C}$ gap at the cell exit. Such a transient implies that the cathode airflow was initially cooling the fuel cell, mostly at the first $25 \%$ of the cell length. Decreasing the temperature gap across the fuel cell length reduced the heat exchange from the solid to the air flow. Therefore, the cooling process progressed slowly as the air delivered through the end of the cell. Likewise, reducing the temperature difference at $100 \mathrm{~s}$ after the fuel transition also lowered the cooling impact of air flow at the inlet region.

The results in Figure 22a also show that as soon as $250 \mathrm{~s}$ after the transient, the cathode inlet airflow was being used to heat the beginning of the cell. This occurred once the solid temperature dropped below the gas temperature due to the rapid heat consumption in SMR, reducing the temperature difference to negative values. The thermal effects of cathode airflow was far more complicated in the period between 1,500 $\mathrm{s}$ after the transient to the final state, in which the heating and the cooling effects of cathode airflow alternated as moving from the inlet down through the cell outlet. But in this period, the airflow cooled the downstream region more than in the initial steady state.

As such, this work reveals the real challenges in modulation of airflow for thermal management of SOFC/GT hybrid system for fuel composition changes. Alternative strategies might need to be considered to compensate for the variations in solid temperature due to methane reforming and the impact of cathode airflow. 

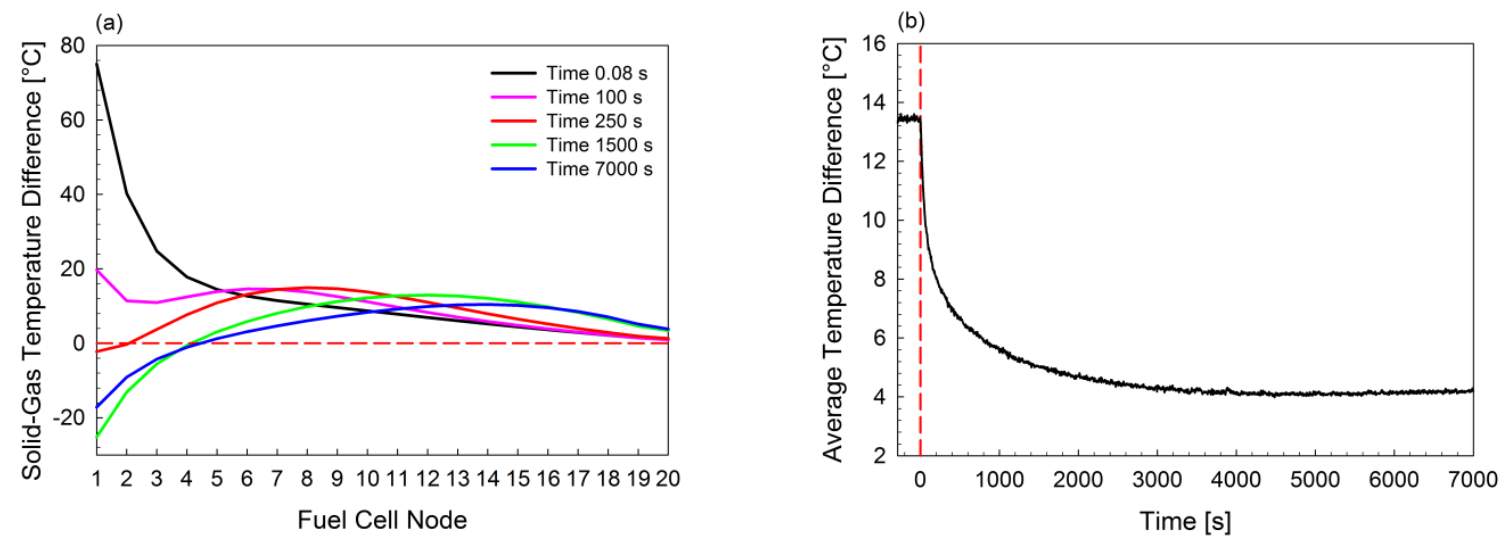

Figure 21: The profile of solid-gas temperature difference $\left(T_{\text {solid }}-T_{\text {gas }}\right)$, (a) Distributed temperature profile across the cell at different time, and (b) Average temperature difference as function of time

\subsection{Dynamic Response of Fuel Cell Thermal Effluent}

Previous studies of the SOFC/GT hybrid system show that the fuel cell waste heat in the direct fired SOFC/GT hybrid configuration is a very important process variable for system performance controls and safety [30].
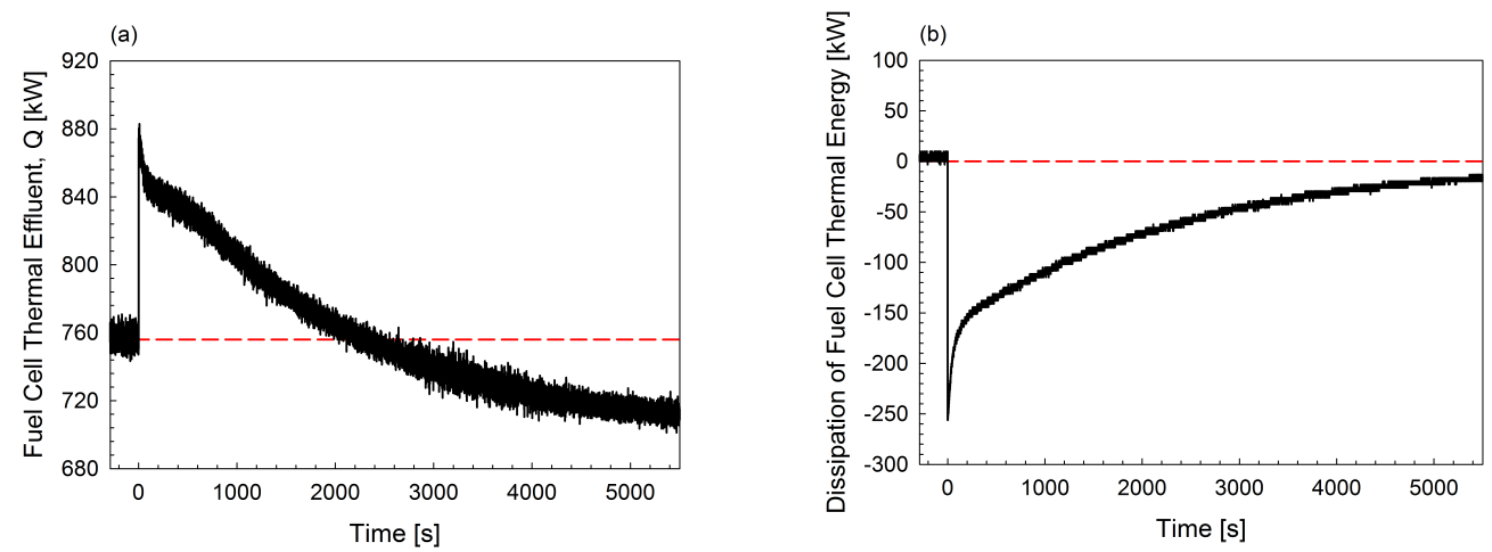

Figure 22: (a) Fuel cell model thermal effluent transient, (b) Dissipation of fuel cell thermal energy storage

When the humidified methane was fed into the anode, methane reformation occurred immediately, as observed in Figure 5. This reaction was initially driven by the elevated fuel cell thermal energy provided in the cathode stream as well as the available chemical energy level contained in the fuel mixture. However, the available energy state was insufficient to facilitate the reactions while maintaining the fuel cell temperature. As such, the fuel cell thermal energy storage was extracted, resulting in a sudden initial increase in fuel cell thermal effluent in a short term period, as highlighted in Figure 22. As shown in Figure 22b, the dissipation rate of thermal energy stored in the fuel cell was $260 \mathrm{~kW}$ immediately after the fuel transition. This thermal energy was transformed to chemical energy via the reforming reaction which increased the low heating value (LHV) of the anode effluent. This subsequently increased the fuel cell thermal effluent, which then increased the thermal energy entering the turbine by $120 \mathrm{~kW}$, or about $17 \%$. This in turn caused an increase in turbine exhaust temperature, which caused a higher heating duty in E300 and E305, which finally caused the rise in cathode inlet temperature discussed previously (Figures 16 and 19).

The total mass-heat capacity contained in the simulated 2500 cell-stack with a total mass of $3500 \mathrm{~kg}$ was approximately $2625 \mathrm{~kJ} / \mathrm{K}$. Under the nominal operating condition, the fuel cell itself stored approximately 2.1 GJ of thermal energy. Theoretically, reducing the temperature of the fuel cell average temperature by $142{ }^{\circ} \mathrm{C}$ over the 7,000 s test (Figure 18) would significantly decrease the total thermal energy storage in the fuel cell by about $18 \%$. Approaching the new steady state, $Q$ decreased gradually, following the reduction in LHV of the fuel feed. As the result of highly coupled interactions in SOFC/GT hybrid system, this dynamic transient subsequently reduced the thermal effluent that ultimately decreased the cathode inlet temperature. 


\section{Conclusions}

This work presented the detailed analysis of fuel cell dynamic performance in SOFC/GT hybrid system during a transition from syngas-fuelled to methane-fuelled operation, including the interactive effects among the key operating variables. It was found that it was feasible to suddenly switch from a coal-derived syngas to a humidified methane fuel (with $14 \%$ methane content) and transition to a new steady state within two hours without causing compressor stall or surge, violating SOFC safe operating constraints, or otherwise adversely affecting the hardware or functionality of the SOFC/GT system. It might also be possible to transition from coalsyngas to humidified methane fuels with an even higher energy content if the transition was gradual instead of a step change, although this was a subject for future research.

It was found that the fuel transition exhibited a rapid transient increase of fuel cell thermal effluent by $17 \%$ in the time scale of milliseconds. The primary driver for the dramatic change in thermal effluent was the conversion of thermal energy stored in the fuel cell stack to chemical energy. Over the course of the 7,000 s period studied, $18 \%$ of the total thermal energy stored in the fuel cell stack itself was extracted.

In the initial period after the transient, methane was all used up by node $8(40 \%)$, but node 20 by 7,000 $\mathrm{s}$. As a consequence of the cooling effects of methane reformation, the maximum spatial temperature gradient, $\mathrm{dT} / \mathrm{dx}$, increased from $11 \mathrm{~K} / \mathrm{cm}$ to $16 \mathrm{~K} / \mathrm{cm}$ at around $35 \%$ from the cell inlet $250 \mathrm{~s}$ after initiation of the transient. Maximum current density also increased by $15 \%$, indicating a shift from node 5 (25\%) to node 18 $(90 \%)$.

Thermal management using modulation of cathode air flow could be a potential strategy to mitigate this unfavorable transient impact. However, due to alternating cooling and heating transient effects of cathode air flow observed across the cell, advanced control strategies may be required to mitigate the unfavorable transient impact as well as to increase the flexibility of SOFC/GT hybrid system.

\section{Acknowledgments}

This work was funded by the U.S Department of Energy Crosscutting Research program, implemented through the Strategic Center for Coal in The Office of Fossil Energy. The authors would like to thank Nana Zhou, Paolo Pezzini, Valentina Zaccaria and Dave Ruehl from NETL for their contribution in the execution of the experimentation, and also greatly acknowledge the Universiti Teknologi Malaysia and Ministry of Higher Education Malaysia for financial support.

\section{References}

[1] Adams TA II. Future opportunities and challenges in the design of new energy conversion systems. Comp Chem Eng. 2014; Volume 34:5-14.

[2] Zhang X, Chan SH, Li G, Ho HK, Li J, Feng Z. A review of integration strategies for solid oxide fuel cells. Journal of Power Sources. 2010;195:685-702.

[3] Winkler W, Nehter P, Williams MC, Tucker D, Gemmen R. General fuel cell hybrid synergies and hybrid system testing status. Journal of Power Sources. 2006;159:656-666.

[4] McLarty D, Brouwer J, Samuelsen S. Fuel cell-gas turbine hybrid system design part I: Steady state performance. Journal of Power Sources. 2014;257:412-420.

[5] Restrepo B, Banta LE, Tucker D. Charaterization of a solid oxide fuel cell gas turbine hybrid system based on a factorial design of experiments using hardware simulation. ASME Energy Sustainability and Fuel Cell 2011. Washington DC, U.S.A. 2011. p. 1 - 12.

[6] Braun RJ, Vincent TL, Zhu H, Kee RJ. Analysis, optimization, and control of solid-oxide fuel cell systems. In: Sundmacher K, editor. Advances in Chemical Engineering. Burlington: Elsevier Inc.; 2012. p. 383-446.

[7] Yi Y, Rao AD, Brouwer J, Samuelsen GS. Fuel flexibility study of an integrated 25 KW SOFC reformer system. Journal of Power Sources. 2005;144:67-76.

[8] Santin M, Traverso A, Magistri L. Liquid fuel utilization in SOFC hybrid systems. Applied Energy. 2009;86:2204-2212.

[9] Leone P, Lanzini A, Ortigoza-Villalba GA, Borchiellini R. Operation of a solid oxide fuel cell under direct internal reforming of liquid fuels. Chemical Engineering Journal. 2012;191:349-355.

[10] Cimenti M, Hill JM. Direct utilization of liquid fuels in SOFC for portable applications: Challenges for the selection of alternative anodes. Energies. 2009;2:377-410.

[11] Adams TA II, Nease J, Tucker D, Barton PI. Energy conversion with solid oxide fuel cell systems: A review of concepts and outlooks for the short- and long-term. Industrial \& Engineering Chemistry Research. 2013;52:3089-3111.

[12] Chen Y, Adams TA II, Barton PI. Optimal design and operation of flexible energy polygeneration systems. Ind Eng Chem Res. 2011;50:4553-4566.

[13] Adams TA II, Barton PI. A dynamic two-dimensional heterogeneous model for water gas shift reactors. International Journal of Hydrogen Energy. 2009;34:8877-8891. 
[14] Song TW, Sohn JL, Kim TS, Ro ST. Performance characteristics of a MW-class SOFC/GT hybrid system based on a commercially available gas turbine. Journal of Power Sources. 2005;158:361-367.

[15] Mueller F, Jabbari F, Brouwer J. On the intrinsic transient capability and limitations of solid oxide fuel cell systems. Journal of Power Sources. 2009;187:452-460.

[16] Mueller F, Gaynor R, Auld AE, Brouwer J, Jabbari F, Samuelsen GS. Synergistic integration of a gas turbine and solid oxide fuel cell for improved transient capability. Journal of Power Sources. 2008;176:229-239.

[17] McLarty D, Brouwer J, Samuelsen S. Fuel cell-gas turbine hybrid system design part II: Dynamics and control. Journal of Power Sources. 2014;254:126-136.

[18] Nakajo A, Wuillemin Z, herle JV, Favrat D. Simulation of thermal stress in anode-supported solid oxide fuel cell stacks. Part I: Probability of failure of the cells. Journal of Power Sources. 2009;193:201-215.

[19] Mueller F, Tarroja B, Maclay J, Jabbari F, Brouwer J, Samuelsen S. Design, simulation and control of a 100 MW-class solid oxide fuel cell gas turbine hybrid system. ASME J. Fuel Cell Sci Technol. 2010;7:111.

[20] Traverso A, Magistri L, Massardo AF. Turbomachinery for the air management and energy recovery in fuel cell gas turbine hybrid systems. Energy. 2010;35:764-777.

[21] Gaynor R, Mueller F, Jabbari F, Brouwer J. On control concepts to prevent fuel starvation in solid oxide fuel cells. Journal of Power Sources. 2008;180:330-342.

[22] Zabihian F, Fung AS. Performance analysis of hybrid solid oxide fuel cell and gas turbine cycle (part I): Effects of fuel composition on output power. Journal of the Energy Institute. 2014;87:18-27.

[23] Zabihian F, Fung AS. Performance analysis of hybrid solid oxide fuel cell and gas turbine cycle (part II): Effects of fuel composition on specific work and efficiency. Journal of the Energy Institute. 2014;87:2834.

[24] Hernandez-Pacheco E, Mann MD, Hutton PN, Singh D, Martin KE. A cell-level model for a solid oxide fuel cell operated with syngas from a gasification process. International Journal of Hydrogen Energy. 2005;30:1221 - 1233 .

[25] Ishak F, Dincer I, Zamfirescu C. Energy and exergy analyses of direct ammonia solid oxide fuel cell integrated with gas turbine power cycle. Journal of Power Sources. 2012;212:73-85.

[26] Li Y, Weng Y. Performance study of a solid oxide fuel cell and gas turbine hybrid system designed for methane operating with non-designed fuels. Journal of Power Sources. 2011;196:3824 - 3835

[27] Zabihian F, Fung AS. Performance analysis of hybrid solid oxide fuel cell and gas turbine cycle: Application of alternative fuels. Energy Conversion and Management. 2013;76:571-580.

[28] Chinda P, Brault P. The hybrid solid oxide fuel cell (SOFC) and gas turbine (GT) systems steady state modeling. International Journal of Hydrogen Energy. 2012;37:9237-9248.

[29] Tucker D, Liese E, Gemmen R. Determination of the operating envelope for a direct fired fuel cell turbine hybrid using hardware based simulation. International Colloquium on Environmentally Preferred Advanced Power Generation (ICEPAG) 2009. Newport Beach, California, U.S.A. 2009.

[30] Harun NF, Tucker D, Adams TA II. Fuel composition transients in fuel cell turbine hybrid for polygeneration applications. ASME J. Fuel Cell Sci Technol. 2014;11: 061001-061001-8.

[31] Hughes D, Wepfer WJ, Davies K, Ford JC, Haynes C, Tucker D. A real-time spatial SOFC model for hardware-based simulation of hybrid systems. ASME 2011 9th International Conference on Fuel Cell Science, Engineering and Technology collocated with ASME 2011 5th International Conference on Energy Sustainability. Washington, DC, U.S.A. 2011. p. 409-428.

[32] Tucker D, Liese E, VanOsdol JG, Lawson LO, Gemmen RS. Fuel cell gas turbine hybrid simulation facility design. ASME International Mechanical Engineering Congress and Exposition. New Orleans, Los Angeles, U.S.A. 2003.

[33] Tucker D, Lawson L, Gemmen R. Characterization of air flow management and control in a fuel cell turbine hybrid power system using hardware simulation. ASME Power Conference 2005. Chicago, Illinois, U.S.A. 2005. p. 959-967.

[34] Tucker D, Lawson L, Gemmen R, Dennis R. Evaluation of hybrid fuel cell turbine system startup with compressor bleed. ASME Turbo Expo 2005. Reno, NV, U.S.A. 2005. p. 333-341.

[35] Tucker D, Pezzini P, Banta L. Equivalence ratio startup control of a fuel cell turbine hybrid system. ASME Turbo Expo 2013: Power for Land, Sea and Air. San Antonio, Texas, U.S.A. 2013. p. 1-11.

[36] Pezzini P, Tucker D, Traverso A. Avoiding compressor surge during emergency shut-down hybrid turbine systems. ASME J. Eng. Gas Turbines Power. 2013;135: 102602-102602-10.

[37] Pezzini P, Traverso A, Banta L, Tucker D. Decentralized control strategy for fuel cell turbine hybrid systems. The 57th Annual ISA Power Industry Division Symposium. Scottsdale, Arizona, U.S.A. 2014.

[38] Li M, Powers JD, Brouwer J. A finite volume sofc model for coal-based integrated gasification fuel cell systems analysis. ASME J. Fuel Cell Sci. Technol. 2010;7: 041017-041017-12. 
[39] Achenbach E. SOFC Stack modeling, final report of activity A2, Annex II: Modeling and evaluation of advanced solid oxide fuel cells, International Energy Agency Programme on R, D\&D on Advanced Fuel Cells. Juelich, Germany: International Energy Agency; 1996.

[40] EG\&G Technical Services I. Fuel Cell Handbook. Seventh Edition ed. Morgantown, West Virginia: U.S. Department of Energy, Office of Fossil Energy, National Energy Technology Laboratory; 2004.

[41] Yakabe H, Hishinuma M, Uratani M, Matsuzaki Y, Yasuda I. Evaluation and modeling of performance of anode-supported solid oxide fuel cell. Journal of Power Sources. 2000;86:423-431.

[42] Aguiar P, Adjiman CS, Brandon NP. Anode-supported intermediate temperature direct internal reforming solid oxide fuel cell. Part I: Model-based steady-state performance. Journal of Power Sources. 2004;138:120-136.

[43] Achenbach E. Three-dimensional and time-dependent simulation of a planar solid oxide fuel cell stack. Journal of Power Sources. 1994;49:333-348.

[44] Hughes DO. A hardware-based transient characterization of electrochemical start-up in an SOFC/gas turbine hybrid environment using a 1-D real time SOFC model. Atlanta, Georgia: Georgia Institute of Technology; 2011.

[45] Cheddie DF, Munroe NDH. A dynamic 1D model of a solid oxide fuel cell for real time simulation. Journal of Power Sources. 2007;171:634-643.

[46] Trembly JP, Gemmen RS, Bayless DJ. The effect of coal syngas containing ash3 on the performance of SOFCs: Investigations into the effect of operational temperature, current density and $\mathrm{AsH}_{3}$ concentration. Journal of Power Sources. 2007;171:818-825.

[47] Tucker D, Abreu-Sepulveda M, Harun NF. SOFC lifetime assessment in gas turbine hybrid power systems. ASME J. Fuel Cell Sci. Technol. 2014;11: 051008-051008-7.

[48] Haynes C, Wepfer WJ. 'Design for Power' of a commercial grade tubular solid oxide fuel cell. Energy Conversion and Management. 2000;41:1123-1139. 